Post-print of: Serás-Franzoso, J., et al. "Integrating mechanical and biological control of cell proliferation through bioinspired multieffector materials" in Nanomedicine (Ed. Future medicine), 2015, Vol. 10, No. 5, p. 873-891. The final versión is available at DOI 10.2217/nnm.15.5

\title{
Integrating mechanical and biological control of cell proliferation through bioinspired multi-effector materials
}

\author{
Joaquin Seras-Franzoso ${ }^{1,2,3} \pm$, Witold I. Tatkiewicz ${ }^{2,4} \pm$, Esther Vazquez ${ }^{1,2,3}$, Elena García- \\ Fruitós $^{1,2,3}$, Imma Ratera ${ }^{2,4} *$, Jaume Veciana ${ }^{2,4}$, and Antonio Villaverde ${ }^{1,2,3} *$ \\ ${ }^{1}$ Departament de Genètica i de Microbiologia, Universitat Autònoma de Barcelona, Bellaterra, \\ 08193 Barcelona, Spain \\ ${ }^{2}$ CIBER de Bioingeniería, Biomateriales y Nanomedicina (CIBER-BBN), Bellaterra, 08193 \\ Barcelona, Spain \\ ${ }^{3}$ Institut de Biotecnologia i de Biomedicina, Universitat Autònoma de Barcelona, Bellaterra, \\ 08193 Barcelona, Spain \\ ${ }^{4}$ Department of Molecular Nanoscience and Organic Materials, Institut de Ciència de Materials \\ de Barcelona (CSIC), Bellaterra, 08193 Barcelona, Spain \\ \pm Equally contributed
}

* Corresponding authors
A. Villaverde antoni.villaverde@uab.es
I. Ratera_iratera@icmab.es 


\begin{abstract}
In nature, cells respond to complex mechanical and biological stimuli whose understanding is required for tissue construction in regenerative medicine. However, the full replication of such bimodal effector networks is far to be reached. Engineering substrate roughness and architecture allows regulating cell adhesion, positioning, proliferation, differentiation and survival, and the external supply of soluble protein factors (mainly growth factors and hormones) has been long applied to promote growth and differentiation. Further, bio-inspired scaffolds are progressively engineered as reservoirs for the in situ sustained release of soluble protein factors from functional topographies. We review here how research progresses towards the design of integrative, holistic scaffold platforms based on the exploration of individual mechanical and biological effectors and their further combination.
\end{abstract}

\title{
Keywords
}

Topography; Regenerative medicine; Adhesion proteins; Hydrogels; Growth factor release; Bioscaffolds 


\section{Introduction}

A deep understanding of cell adhesion, positioning, migration, proliferation, apoptosis and differentiation and the precise control of the underlying mechanisms are necessary for the generation of fully functional artificial tissues. The comprehension of how cells organize into complex structures requires the identification of the different participating effectors and how they combine for specific, time-dependent cell responses. This is especially critical for the reconstruction of damaged tissues that involves the controlled cultivation of stem cells on artificial scaffolds, either straightforward in vivo, or ex vivo followed by implantation into damaged organs. In both cases, manmade scaffolds are expected to be biocompatible, mechanically stable and when required fully biodegradable (depending on how the regenerative process has been designed). They must also provide a bio-inspired topography within cell dimensions range to support cell colonization, mimicking to that offered in vivo by the extracellular matrix (ECM). This is because mechanic stimuli have been revealed as critical for cell proliferation, positioning and differentiation, acting through cell sensing and mechanotransduction events ${ }^{(1)}$. Then, the de novo designed scaffolds for tissue engineering must address precise topographical requests at micro and nano scales apart from exhibiting defined material properties affecting cell behavior such as two-dimensional/three-dimensional (2D/3D) geometry, appropriate stiffness and surface charge.

In the ECM, mechanical stimulation is combined with the activity of biological effectors mainly based on soluble molecules such as hormones, growth factors (GF), signal transducers and probably a set of still unidentified agents released by neighboring cells. Also, the ECM itself, based on diverse types of protein materials, displays cell adhesive and topographical properties that regulate cell fate ${ }^{(2)}$. The combined action of biological and mechanical agents generates a complex stimuli pattern that supports the dynamics of tissue formation and vascularization ${ }^{(3)}$. Then, any potential of a synthetic scaffold to act, in addition to topographic modulator, as a reservoir of bioactive compounds for their sustained release is highly appealing, especially for in vivo applications in which external drug supply might be restricted. In this regard, mechanical stimulation in combination with the supply of these factors represents the best approach to mimic the natural cell environment in artificial sets. However, the enormous complexity of the natural effector network and the synergistic activities of their components delay the desirable combined application of modulators in tissue engineering. Then, both type of effectors are often developed and tested separately, and only a moderate number of strategies are addressing the integrative supply of mechanical and biological signals. Importantly, proteins represent particularly intriguing materials as they can provide, simultaneously, architecture and functionality to cell substrates. The main trends in the topographical design of scaffold materials as well as the biological nature of protein-based effectors of relevance in tissue engineering are revised here. We particularly stress emerging developmental routes towards biofunctional scaffolds empowered to present both mechanical and biological stimuli in a cell sensing range. 


\section{Engineering scaffold topography}

Plain topographical stimuli. Synthetic topographies affect basic functions in almost all types of mammalian cells. Therefore, engineering substrates within the size range at which ECM mechanical effectors trigger cell responses ${ }^{(4)}$ offers a powerful tool to study and regulate complex cell functions such as adhesion, migration, cytoskeleton reorganization and cell polarization ${ }^{(5,1)}$ that might be useful and exploitable for specific tissue engineering purposes. Although responses vary across cell type and substrate properties, some general lessons can be extracted from the rapidly growing body of literature (Table 1). These data could then be exploited to iteratively probe, engineer and improve cell-nanotopography interactions for tissue engineering applications though the manipulation of the mechanical stimuli to which cells are exposed ${ }^{(6)}$.

Mechanical stimulation has been explored through the lithographical modification of polymers or other surfaces (top-down approach) to generate micro- and nano-grooves or pits (bottomup approach) ${ }^{(7,8)}$. The use of such modified substrates permits, in addition, the regulation of the expression of cell adhesion molecules ${ }^{(9)}$, the distribution of focal adhesions ${ }^{(10)}$ and the orientation of whole cells as well as their morphological appearance ${ }^{(11)}$. Microcontact printing $(\mu C P)^{(12)}$ is recognized as a cost-effective, fast and versatile technique to control surface chemistry at the microscale over considerably large areas (up to hundreds of $\mathrm{mm}^{2}$ ). The range of materials that can be used to cover surfaces using this method is broad ${ }^{(13)}$ : self-assembled monolayers (SAM's) ${ }^{(14)}$, proteins ${ }^{(15)}$ and nucleic acids ${ }^{(12)}$ among others giving rise to functional surfaces ${ }^{(16)}$ which are obtained by multistep protocols. Although in most cases the "ink" used in this printing procedure consists of a solution of the molecules of interest, such softlithographic method can also be extended to pattern colloidal particles ${ }^{(17)}$ or even bacterial cells ${ }^{(18)}$, expanding the functionalities of the engineered surface.

Alternatively, several categories of particulate materials have been explored for the nanomorphological modification of scaffold surfaces (bottom-up approach), including ceramics, polymers and nanotubes ${ }^{(19,20,21,22)}$. Particle-based surface decoration is highly promising since it is less dependent on the chemical nature of the scaffold material in contrast to lithographical modification. It allows, in some materials, important levels of topographical flexibility and controllable effects on cells, as exemplified by the use of nanotubes as substrate modifiers. In this context, the viability and activity of $\mathrm{MSCs}$ cultured on $\mathrm{TiO}_{2}$ nanotubes can be controlled by the tube diameter ${ }^{(23)}$. Vertically aligned $\mathrm{TiO}_{2}$ nanotubes with a diameter larger than $50 \mathrm{~nm}$ dramatically reduced cell activity and caused programmed cell apoptosis. Compared to smooth $\mathrm{TiO}_{2}$ surfaces, a lateral spacing of 15-30 nm strongly promoted focal contact formation and enhanced cell activities ${ }^{(24)}$. Using this platform, the influence of integrated nanoscaled topography and GFs to stem-cell fate has also been investigated, facilitating the further developments of medical implants and materials.

Combined topographical stimuli. In this context, recent approaches focus on two or more combined engineering strategies to achieve complex combined stimuli. Hot embossing has been applied to control topography and $\mu \mathrm{CP}$ for a chemical patterning, to obtain substrates with grooves covered with perpendicular stripes of proteins ${ }^{(25)}$, while a similar architecture has been also generated but with parallel patterns ${ }^{(26)}$. Recknor and coauthors co-cultured 
astrocytes with adult rat hippocampal progenitor cells over chemically modified micropatterned polystyrene substrates and they preferentially acquire neuronal morphology depending on the microstructuration of the substrate ${ }^{(27)}$. These examples indicated that substrate topography in synergy with chemical modification and biological guidance facilitates cell differentiation. Also in this regard, we have recently shown that bacterial inclusion bodies (IBs), pseudospherical protein clusters spontaneously formed in recombinant bacteria, can be used as biocompatible materials for surface decoration and stimulation of mammalian cell spread. Since IB formation is multigenetically determined through the cell quality control system, mechanical, morphological, structural and biological properties of IBs can be adjusted by the genetic manipulation of the producing cells. IBs show a positive impact on colonization and proliferation ${ }^{(28,29)}$, and being highly bioadhesive materials, cell expansion on IB-decorated surfaces has been proven to be synergistically supported by both favored adhesion and mechanical stimulation of cell division ${ }^{(30)}$. In micropatterned surfaces, cells preferentially adhere to IB-rich areas, aligning and elongating according to the IB pattern and choosing the shortest way to reach new adhesion spots on the IBs ${ }^{(31)}$. Such $2 \mathrm{D}$ engineering technique fills the gap between existing techniques which are based on the local modification of the chemical nature of the surface and those based on the modification of the topography at the nanoscale level by physical methods because IBs combine at the same time biofunctionalization and topographical modification of the roughness, as discussed in more detail above.

3D topographies. 3D scaffolds are expected to mimic the ECM and the natural cell environment more accurately than conventional 2D surfaces. Apart from metals, ceramics, protein-based hydrogels and carbon nanotubes, a spectrum of biocompatible and biodegradable polymers is being explored for ex vivo 3D culture and subsequent implantation, including hyaluronic acid (HA), polylactic acid (PLA), polyglycolic acid (PLGA), chitosan $(\mathrm{CHT})$, hydroxyapatite, polycaprolactone $(\mathrm{PCL})$, polyanhydrides, polyorthoesters and dendrimers ${ }^{(32,33,34)}$. Controlling the material architecture during biofabrication permits the pre-definition of porosity for mass transfer and proper colonization of the inner surfaces.

In addition, 3D scaffolds are expected to offer disordered mechanical stimuli for mechanotransduction events ${ }^{(35,36)}$, required for a fine control of cell response, more efficiently than $2 \mathrm{D}$ substrates. Since ideally, mechanical stimulation should act synergistically with biological signals, 3D scaffolds might be appropriate as combined with sets of soluble factors embedded in the matrices, as discussed in deep below. This is exemplified by the emerging biomimetic materials used in implants for bone regeneration such as nano-hydroxyapatite/polyamide66 and derivatives ${ }^{(37)}$ that show excellent biocompatibility, stability and osteoconductivity. When used in the fabrication of screws can be loaded with GFs to confer additional biological activities to the material and successfully fix intercondylar femur fractures ${ }^{(38)}$. In addition, related hydroxyapatite materials can be loaded with antibiotics for sustained release in vivo to prevent bacterial infections subsequent to surgery ${ }^{(39)}$. 
Table 1. Topographical control of cell proliferation, morphology and positioning, illustrated by representative examples.

\begin{tabular}{|c|c|c|c|c|c|c|}
\hline & & & \multicolumn{2}{|c|}{ Feature geometry } & \multirow[t]{2}{*}{ Impact on cell } & \multirow[t]{2}{*}{ Reference } \\
\hline $\begin{array}{l}\text { Substrate } \\
\text { material }\end{array}$ & Feature type & Cell type & Width & Depth & & \\
\hline Quartz & Grooves & $\begin{array}{l}\text { Murine } \\
\text { P388D1 } \\
\text { macrophage }\end{array}$ & $\begin{array}{l}0.5,5,10, \\
25 \mu \mathrm{m}\end{array}$ & $\begin{array}{l}0.5 \\
5 \mu \mathrm{m}\end{array}$ & $\begin{array}{l}\text { Orientation } \\
\text { change and } \\
\text { Elongation, more } \\
\text { in wider grooves }\end{array}$ & (40) \\
\hline Quartz & Grooves & $\begin{array}{l}\text { Mesenchymal } \\
\text { stem cells }\end{array}$ & $1.4 \mu \mathrm{m}$ & $1.1 \mu \mathrm{m}$ & $\begin{array}{l}\text { Alignment better } \\
\text { in the widest } \\
\text { grooves }\end{array}$ & (41) \\
\hline Quartz & Grooves & Fibroblasts & $12.5 \mu \mathrm{m}$ & $5 \mu \mathrm{m}$ & $\begin{array}{l}\text { Gene expression } \\
\text { largely changed }\end{array}$ & (42) \\
\hline Quartz & Grooves & $\begin{array}{l}\text { Murine } \\
\text { macrophages }\end{array}$ & $2-10 \mu \mathrm{m}$ & $\begin{array}{l}30-280 \\
\mathrm{~nm}\end{array}$ & $\begin{array}{l}\text { Higher } \\
\text { phagocytotic } \\
\text { activity when } \\
\text { topography fiber }\end{array}$ & (43) \\
\hline Quartz & Grooves & $\begin{array}{l}\text { Human } \\
\text { corneal ECs }\end{array}$ & $1-4 \mu \mathrm{m}$ & $\mathrm{N} / \mathrm{D}$ & Elongation & (44) \\
\hline Silicon & Grooves & $\begin{array}{l}\text { Humancornea } \\
\text { I epithelial } \\
\text { cells }\end{array}$ & $\begin{array}{l}330- \\
2100 \mathrm{~nm}\end{array}$ & $600 \mathrm{~nm}$ & $\begin{array}{l}\text { Perpendicular } \\
\text { alignment for } \\
400-800 \mathrm{~nm} \\
\text { pitch. Parallel for } \\
1600-4000 \mathrm{~nm}\end{array}$ & (45) \\
\hline Silicon dioxide & Grooves & Fibroblasts & $0.5 \mu \mathrm{m}$ & $1 \mu \mathrm{m}$ & Strong alignment & (46) \\
\hline Silicon dioxide & Grooves & Keratinocytes & $0.5 \mu \mathrm{m}$ & $1 \mu \mathrm{m}$ & No alignment & (46) \\
\hline PMMA & Grooves & BHK cells & $\begin{array}{l}2,3,6,12 \\
\mu \mathrm{m}\end{array}$ & $\begin{array}{l}0.2,0.5 \\
1.1,1.9 \\
\mu \mathrm{m}\end{array}$ & $\begin{array}{l}\text { Alignment } \\
\text { increased with } \\
\text { depth and } \\
\text { decreased with } \\
\text { width } \\
\end{array}$ & (47) \\
\hline PMMA & Steps & $\mathrm{BHK}$ & $1-18 \mu \mathrm{m}$ & $\mathrm{N} / \mathrm{D}$ & $\begin{array}{l}\text { Alignment at } \\
\text { steps }\end{array}$ & (47) \\
\hline PMMA & Pillars & Fibroblasts & $100 \mathrm{~nm}$ & $160 \mathrm{~nm}$ & $\begin{array}{l}\text { Smaller, less } \\
\text { organized actin } \\
\text { cytoskeleton }\end{array}$ & (48) \\
\hline PCL,PMMA & Pits & Fibroblasts & $\begin{array}{l}35 \\
75,120 n \\
m\end{array}$ & $N / D$ & $\begin{array}{l}\text { Reduced } \\
\text { adhesion, } \\
\text { orientation and } \\
\text { distinction of } \\
\text { symmetries } \\
\end{array}$ & $(49,50,51)$ \\
\hline PCL, PMMA & Nanopit & $\begin{array}{l}\text { Human } \\
\text { fibroblasts }\end{array}$ & $\begin{array}{l}35-120 \\
\mathrm{~nm}\end{array}$ & $\mathrm{~N} / \mathrm{D}$ & $\begin{array}{l}\text { Adhesion } \\
\text { decreased and } \\
\text { biased orientation }\end{array}$ & (52) \\
\hline $\mathrm{PCL}$ & Nanopit & $\begin{array}{l}\text { Human } \\
\text { fibroblasts }\end{array}$ & $\begin{array}{l}35-120 \\
\mathrm{~nm}\end{array}$ & $N / D$ & $\begin{array}{l}\text { Spreading } \\
\text { decresed. } \\
\text { Increased } \\
\text { filopodia }\end{array}$ & (53) \\
\hline $\mathrm{PCL}$ & $\begin{array}{l}\text { Nanopit and } \\
\text { nanopost }\end{array}$ & $\begin{array}{l}\text { Rat } \\
\text { fibroblasts }\end{array}$ & $\begin{array}{l}\text { 60-150 } \\
\mathrm{nm}\end{array}$ & $N / D$ & $\begin{array}{l}\text { Adhesion } \\
\text { decreased and } \\
\text { increased } \\
\text { adhesion on } \\
\text { random }\end{array}$ & (54) \\
\hline
\end{tabular}




\begin{tabular}{|c|c|c|c|c|c|c|}
\hline & & & & & nanoposts & \\
\hline PS & Grooves & $\begin{array}{l}\text { Rat } \\
\text { astrocytes }\end{array}$ & $10 \mu \mathrm{m}$ & $3 \mu \mathrm{m}$ & $\begin{array}{l}\text { Less adhesion, } \\
\text { strong alignment }\end{array}$ & (55) \\
\hline PS & Grooves & Fibroblasts & $\begin{array}{l}20- \\
1000 \mathrm{~nm}\end{array}$ & $\begin{array}{l}5- \\
530 \mathrm{~nm}\end{array}$ & $\begin{array}{l}\text { No alignment for } \\
\text { depths }<35 \mathrm{~nm} \text { or } \\
\text { widths }<100 \mathrm{~nm}\end{array}$ & (56) \\
\hline PS & Grooves & Rat bone cells & $1-10 \mu \mathrm{m}$ & $\begin{array}{l}0.5-1.5 \\
\mu \mathrm{m}\end{array}$ & $\begin{array}{l}\text { Width }>5 \mu \mathrm{m} \text { : } \\
\text { cells followed the } \\
\text { surface. Narrow } \\
\text { grooves: cells } \\
\text { bridge }\end{array}$ & (57) \\
\hline PS & Grooves & $\begin{array}{l}\text { Rat bone } \\
\text { marrow cells, } \\
\text { osteoblasts } \\
\text { MC3TC }\end{array}$ & $\begin{array}{l}\text { Micro } \\
\text { (manual) }\end{array}$ & N/D & $\begin{array}{l}\text { RBMC influenced } \\
\text { by grooves } \\
\text { (osteoblast } \\
\text { differentiation) } \\
\text { MC3T4 not } \\
\text { influenced }\end{array}$ & (58) \\
\hline PS & Grooves & rC6 glioma & $266 \mathrm{~nm}$ & $\mathrm{~N} / \mathrm{D}$ & Elongation & (59) \\
\hline PS & Grooves & $\begin{array}{l}\text { hEKCS (HEK- } \\
\text { 293) }\end{array}$ & $\begin{array}{l}200-430 \\
\mathrm{~nm}\end{array}$ & $\mathrm{~N} / \mathrm{D}$ & $\begin{array}{l}\text { Elongation. } \\
\text { Increased } \\
\text { proliferation }\end{array}$ & (60) \\
\hline PS & Grooves & $\begin{array}{l}\text { Human } \\
\text { corneal ECs }\end{array}$ & $2-20 \mu \mathrm{m}$ & $\mathrm{N} / \mathrm{D}$ & $\begin{array}{l}\text { Elongation, lower } \\
\text { cell area. }\end{array}$ & (61) \\
\hline PS & Grooves & Rat bone cells & $1-10 \mu \mathrm{m}$ & $\begin{array}{l}0.5- \\
1.5 \mu \mathrm{m}\end{array}$ & $\begin{array}{l}\text { Large grooves: } \\
\text { focal adhesions all } \\
\text { over the surface; } \\
\text { Narrow grooves: } \\
\text { only on the edges }\end{array}$ & (57) \\
\hline PS & Nanopost & HeLA & $\begin{array}{l}160-1000 \\
\mathrm{~nm}\end{array}$ & $\mathrm{~N} / \mathrm{D}$ & $\begin{array}{l}\text { Spreading } \\
\text { decreased. No } \\
\text { effect on } \\
\text { proliferation }\end{array}$ & (62) \\
\hline $\mathrm{PS}$ and $\mathrm{PBrS}$ & Random & $\begin{array}{l}\text { Human } \\
\text { endothelial }\end{array}$ & $\begin{array}{l}13,35,95 \\
n m\end{array}$ & N/D & $\begin{array}{l}\text { Round cells on PS, } \\
\text { Arcuate } \\
\text { morphology } \\
\text { largest for the } 13 \\
\mathrm{~nm} \text { islands }\end{array}$ & (63) \\
\hline Polyimide & Grooves & Osteoblasts & $4 \mu \mathrm{m}$ & $5 \mu \mathrm{m}$ & $\begin{array}{l}\text { Strong alignment } \\
\text { and elongation no } \\
\text { changes in } \\
\text { adhesion }\end{array}$ & (64) \\
\hline PDLA & Grooves & $\begin{array}{l}\text { Schwann cells } \\
\text { (nerve cells) }\end{array}$ & $10 \mu \mathrm{m}$ & $3 \mu \mathrm{m}$ & Strong alignment & (65) \\
\hline PLGA, PU, PCL & Random & $\begin{array}{l}\text { Bladdersmoot } \\
\mathrm{h} \\
\text { Muscle cells }\end{array}$ & $\begin{array}{l}206, \\
370 \mathrm{~nm}\end{array}$ & $\mathrm{~N} / \mathrm{D}$ & $\begin{array}{l}\text { Enhanced } \\
\text { adhesion }\end{array}$ & $(66)$ \\
\hline Epoxy & Grooves & $\begin{array}{l}\text { Human } \\
\text { fibroblasts }\end{array}$ & $0.5 \mu \mathrm{m}$ & $1 \mu \mathrm{m}$ & $\begin{array}{l}\text { Cytoskeleton } \\
\text { oriented with } \\
\text { grooves }\end{array}$ & (67) \\
\hline PLLA, PS & Grooves & Rat bone cells & $\begin{array}{l}1,2,5,10 \mu \\
\mathrm{m}\end{array}$ & $\begin{array}{l}0.5,1,1 \\
5 \mu \mathrm{m}\end{array}$ & $\begin{array}{l}\text { Better } \\
\text { mineralization } \\
\text { with feature } \\
\text { diameter of } 1 \mu \mathrm{m} \\
\text { and feature width } \\
\text { of } 1-2 \mu \mathrm{m}\end{array}$ & (68) \\
\hline PDMS & Grooves & $\begin{array}{l}\text { Human } \\
\text { embryonic } \\
\text { stem cells } \\
\end{array}$ & $600 \mathrm{~nm}$ & $600 \mathrm{~nm}$ & $\begin{array}{l}\text { Reduced } \\
\text { proliferation }\end{array}$ & (69) \\
\hline PDMS & Wells & $\begin{array}{l}\text { Human } \\
\text { fibroblasts }\end{array}$ & $2,5,10 \mu \mathrm{m}$ & $\mathrm{N} / \mathrm{D}$ & $\begin{array}{l}\text { With } 2 \text { and } 5 \mu \mathrm{m} \\
\text { better } \\
\text { proliferation. } 10 \\
\mathrm{~mm} \text { has no effect }\end{array}$ & (70) \\
\hline
\end{tabular}




\begin{tabular}{|c|c|c|c|c|c|c|}
\hline PDMS & Grooves & $\begin{array}{l}\text { Human } \\
\text { endothelial } \\
\text { cells }\end{array}$ & $600 \mathrm{~nm}$ & $\mathrm{~N} / \mathrm{D}$ & $\begin{array}{l}\text { Decreased } \\
\text { proliferation. } \\
\text { Elongation, lower } \\
\text { cell area } \\
\end{array}$ & (71) \\
\hline PDMS & Grooves & $\begin{array}{l}\text { Human } \\
\text { embryonic } \\
\text { stem cells }\end{array}$ & $600 \mathrm{~nm}$ & $N / D$ & $\begin{array}{l}\text { Elongation. } \\
\text { Adhesion } \\
\text { decreased and } \\
\text { decreased } \\
\text { proliferation, } \\
\text { cytoskeleton } \\
\text { disrupting agents } \\
\text { impact response }\end{array}$ & (69) \\
\hline PDMS & Grooves & $\begin{array}{l}\text { Human } \\
\text { mesenchymal } \\
\text { stem cells }\end{array}$ & $\begin{array}{l}350 \mathrm{~nm}- \\
10 \mu \mathrm{m}\end{array}$ & $N / D$ & $\begin{array}{l}\text { Elongation, lower } \\
\text { cell area. } \\
\text { Decreased } \\
\text { proliferation, } \\
\text { differentiation } \\
\text { into neuronal } \\
\text { lineage }\end{array}$ & $(72)$ \\
\hline PMMA & Wells, random & $\begin{array}{l}\text { Human } \\
\text { mesenchymal } \\
\text { stem cells }\end{array}$ & $120 \mathrm{~nm}$ & $100 \mathrm{~nm}$ & $\begin{array}{l}\text { Stimulated } \\
\text { differentiation } \\
\text { and production of } \\
\text { bone mineral in } \\
\text { vitro }\end{array}$ & (36) \\
\hline PMMA & Random & $\begin{array}{l}\text { Bone marrow } \\
\text { cells (stem } \\
\text { cells) }\end{array}$ & $\begin{array}{l}100- \\
2000 \mathrm{~nm}\end{array}$ & N/D & $\begin{array}{l}\text { Differentiation to } \\
\text { osteoblasts } \\
\text { promoted, cells } \\
\text { organize into } \\
\text { superstructures }\end{array}$ & $(73)$ \\
\hline PMMA & Nanopit & $\begin{array}{l}\text { Human } \\
\text { mesenchymal } \\
\text { stem cells }\end{array}$ & $300 \mathrm{~nm}$ & $\mathrm{~N} / \mathrm{D}$ & $\begin{array}{l}\text { Osteogenic } \\
\text { differentiation }\end{array}$ & $(36)$ \\
\hline PMMA & Pillars & Fibroblasts & $100 \mathrm{~nm}$ & $160 \mathrm{~nm}$ & Less spreading & (74) \\
\hline PDMS, PMMA & Grooves & $\begin{array}{l}\text { Bovine } \\
\text { smooth } \\
\text { muscle cells }\end{array}$ & $350 \mathrm{~nm}$ & $N / D$ & $\begin{array}{l}\text { Elongation. } \\
\text { Decreased } \\
\text { proliferation, } \\
\text { polarized } \\
\text { microtubule } \\
\text { organization } \\
\text { center }\end{array}$ & (75) \\
\hline PLGA & Random & $\begin{array}{l}\text { Rat aortic } \\
\text { smooth } \\
\text { muscle cells, } \\
\text { rat aortic } \\
\text { endothelial } \\
\text { cells }\end{array}$ & $\begin{array}{l}\text { Nano- } \\
\text { range }\end{array}$ & $\mathrm{N} / \mathrm{D}$ & $\begin{array}{l}\text { Improve on cell } \\
\text { densities with the } \\
\text { nanostructure }\end{array}$ & $(76)$ \\
\hline PEG & Nanopost & $\begin{array}{l}\text { Rat } \\
\text { cardiomyocyt } \\
\text { es }\end{array}$ & $150 \mathrm{~nm}$ & $\mathrm{~N} / \mathrm{D}$ & $\begin{array}{l}\text { Adhesion } \\
\text { increased }\end{array}$ & (77) \\
\hline PEG & Nanopost & $\begin{array}{l}\text { mP19EC stem } \\
\text { cells }\end{array}$ & $\begin{array}{l}300-500 \\
\mathrm{~nm}\end{array}$ & $\mathrm{~N} / \mathrm{D}$ & $\begin{array}{l}\text { Adhesion } \\
\text { increased }\end{array}$ & $(78)$ \\
\hline PC & Nanopit & $\begin{array}{l}\text { Human bone } \\
\text { marrow cells }\end{array}$ & $300 \mathrm{~nm}$ & $\mathrm{~N} / \mathrm{D}$ & $\begin{array}{l}\text { Spreading } \\
\text { decresed. } \\
\text { Constant filopodia } \\
\text { formation N/D }\end{array}$ & (79) \\
\hline PC & Nanopit & $\begin{array}{l}\text { Human } \\
\text { osteoblasts }\end{array}$ & $300 \mathrm{~nm}$ & $\mathrm{~N} / \mathrm{D}$ & $\begin{array}{l}\text { Adhesion } \\
\text { decreased. } \\
\text { Reduced area of } \\
\text { adhesion } \\
\text { complexes }\end{array}$ & (80) \\
\hline PGS & Grooves & $\begin{array}{l}\text { Bovine } \\
\text { endothelial }\end{array}$ & $2 \mu \mathrm{m}$ & $\mathrm{N} / \mathrm{D}$ & Elongation & $(81)$ \\
\hline
\end{tabular}




\begin{tabular}{|c|c|c|c|c|c|c|}
\hline & & cells & & & & \\
\hline $\mathrm{Si}$ & Nanopost & Fibroblasts & $\begin{array}{l}50-600 \\
\mathrm{~nm}\end{array}$ & N/D & $\begin{array}{l}\text { Spreading } \\
\text { decresed. No } \\
\text { effect on } \\
\text { proliferation }\end{array}$ & $(82)$ \\
\hline $\mathrm{Si}$ & Grooves & PC12 & $\begin{array}{l}70-1900 \\
\mathrm{~nm}\end{array}$ & $\mathrm{~N} / \mathrm{D}$ & $\begin{array}{l}\text { Elongation. } \\
\text { Cooperative } \\
\text { neurite extension }\end{array}$ & $(83)$ \\
\hline $\mathrm{Si}$ & Nanopit & $\begin{array}{l}\text { Human } \\
\text { fibroblasts }\end{array}$ & $80 \mathrm{~nm}$ & $\mathrm{~N} / \mathrm{D}$ & $\begin{array}{l}\text { Spreading } \\
\text { decresed }\end{array}$ & (79) \\
\hline $\mathrm{Si}$ & Grooves & $\begin{array}{l}\text { Human } \\
\text { corneal ECs }\end{array}$ & $\begin{array}{l}70-2100 \\
\mathrm{~nm}\end{array}$ & N/D & $\begin{array}{l}\text { Elongation, lower } \\
\text { cell area. } \\
\text { Adhesion } \\
\text { increased. Biased } \\
\text { lamellipodioa } \\
\text { extension }\end{array}$ & $(45,84)$ \\
\hline $\mathrm{Si}$ & Grooves & $\begin{array}{l}\text { Human } \\
\text { fibroblasts }\end{array}$ & $\begin{array}{l}50-600 \\
\mathrm{~nm}\end{array}$ & $\mathrm{~N} / \mathrm{D}$ & $\begin{array}{l}\text { Elongation, lower } \\
\text { cell area. } \\
\text { Decreased } \\
\text { proliferation }\end{array}$ & $(82)$ \\
\hline $\mathrm{Ti}$ & Grooves & Fibroblasts & $3-5 \mathrm{~nm}$ & $\mathrm{~N} / \mathrm{D}$ & $\begin{array}{l}\text { Elongation. No } \\
\text { effect, increase in } \\
\text { fibronectin mRNA } \\
\text { incorporation }\end{array}$ & $(85)$ \\
\hline $\mathrm{Ti}$ & Grooves & $\begin{array}{l}\text { Rat } \\
\text { endothelial } \\
\text { cells }\end{array}$ & $\begin{array}{l}750 \mathrm{~nm}- \\
10 \mu \mathrm{m}\end{array}$ & N/D & $\begin{array}{l}\text { Increased } \\
\text { adhesion and } \\
\text { longation }\end{array}$ & $(86)$ \\
\hline Ti-coated Si & Grooves & $\begin{array}{l}\text { T24, human } \\
\text { bladder } \\
\text { carcinoma }\end{array}$ & $15 \mu \mathrm{m}$ & $200 \mathrm{~nm}$ & $\begin{array}{l}\text { Nanopillars: less } \\
\text { round and more } \\
\text { stellate, smaller } \\
\text { Grooves: } \\
\text { elongatio }\end{array}$ & $(87)$ \\
\hline Alumina & Pillars, pores & $\begin{array}{l}\text { Mouse } \\
\text { marrow } \\
\text { stromal cells }\end{array}$ & $\begin{array}{l}110,72 \\
\mathrm{~nm}\end{array}$ & $\mathrm{~N} / \mathrm{D}$ & $\begin{array}{l}\text { Proliferation } \\
\text { increased } 45 \% \\
\text { increased } \\
\text { osteoblast } \\
\text { differentiation }\end{array}$ & $(88)$ \\
\hline $\begin{array}{l}\text { Silica on PEI- } \\
\text { coated silicon } \\
\text { gradient } \\
\text { concentration }\end{array}$ & Beads & $\begin{array}{l}\text { Rat calvarial } \\
\text { osteoblasts }\end{array}$ & $73 \mathrm{~nm}$ & $73 \mathrm{~nm}$ & $\begin{array}{l}\text { Particles } \\
\text { (nanotopography) } \\
\text { reduced cell } \\
\text { proliferation }\end{array}$ & $(89)$ \\
\hline
\end{tabular}

Abbreviationlist:N/D:non-determined;PMMA:poly(methylmethacrylate);PDMS: poly-dimethyl siloxane; PC: polycarbonate; PS: polystyrene; PLLA: poly(L-lactideacid); PET: poly(ethyleneterephthalate); PBrS: poly(4bromostyrene); PCL: polycaprolactone; PDLA: poly(D,L-lactic acid); PLGA: polylactic-co-glycolic-acid; PU: polyetherurethane.

\section{Tailoring bio-functional protein materials}

Promoting cell adhesion through protein coating. Often, fabrication constraints, biocompatibility, durability and the need to control precise architectural, topographical or chemical profiles impose the use of unfriendly materials as prototype scaffolds for tissue engineering. Coating these scaffolds with ECM proteins such as fibronectin (FN), the most adhesive glycoprotein, collagen I or III, laminin-I, elastin and vitronectin facilitates cell adhesion and colonization (Table 2). These proteins adsorb to almost any surface, including metals, 
organic biopolymers and ceramics ${ }^{(90)}$, by binding forces responsible for the "Vroman effect" ${ }^{(91)}$. Due to their difficult extraction from natural sources, many ECM proteins have been produced in recombinant forms. Since during adsorption full-length proteins may suffer conformational changes that hide functional domains critical for cell interaction ${ }^{\left({ }^{2}\right)}$, coating with functional ECM protein fragments, like the 120-KDa FN segment or peptide epitopes like RGD (Arg-Gly-Asp), found in many adhesive ECM glycoproteins, might be highly convenient. RGD motives need to maintain its native stereo conformation (cyclic form) to exhibit full binding activity (240 times more active than the linear peptide) ${ }^{(93)}$, what poses important challenges in peptide design and synthesis. Other integrin-binding peptides from ECM are REVD, KQAGDV and PHSRN derived from FN; YIGSR, IKLLI, LRE, LRGDN, PDGSR, LGTIPG and IKVAV derived from laminin or GFOGER p15 and DGEA derived from collagen. Scaffold coating with adhesive ECM epitopes gives the opportunity to control not only peptide density but also clustering through nanopatterning, which in turns regulates cytoskeletal organization, focal contact, proliferation, adhesion and differentiation ${ }^{(94)}$, as discussed above.

Also, scaffolds themselves can be made of collagen, elastin or polysaccharide nanofibers like hialuronic acid (HA), cellulose, alginate, chitin and chitosan. Scaffolds of native collagen type I have been extensively used in cell biology and 3D collagen gels have been successfully applied to skin regeneration and cartilage repair, as they promote convenient cellular behavior in terms of migration, shape and differentiation. Scaffolds of native and recombinant elastin have been used in vivo for tissue engineering of skin and vascular tissues with promising results. On the other hand, HA scaffolds are widely employed in ophthalmology, as joint lubricants and in tissue engineering of cartilage and skin, due to the pleiotropic cellular effects derived from HACD44 interaction (for a review, see ${ }^{(95)}$ ). Finally, keratin biomaterials derived from human hair are suitable to induce cell adhesion, proliferation and migration ${ }^{(96)}$.

In a related scenario, elastin-like polypeptides (ELPs) are recombinant alternatives derived from elastin, which maintain biocompatibility for in vivo applications and show structural responsiveness to temperature. ELPs are formed by repeats of the elastin primary sequence VPGXG. They are used to construct scaffolds for the regeneration of different tissues (dermal, vascular, cardiac, cartilage), but also to coat different materials too hydrophobic or negatively charged to allow cell adhesion and growth ${ }^{(97)}$.

Unconventional and emerging adhesive proteins. Silk fibroin (SF), a silk protein produced by silkworms, exhibits excellent biocompatibility, good oxygen and water vapor permeability, biodegradability, triggering a minimal inflammatory reaction ${ }^{(98)}$. In practice, SF has been used in cosmetics, as a medical material in human medicine and as food additive. Electrospun SF matrices have been developed as a support for culture of fibroblasts and keratinocytes ${ }^{(99)}$, bone marrow stem cells (BMSC) ${ }^{(100)}$, human aortic endothelial cells (HAEC) and human coronary artery smooth muscle cells (HCASMC) ${ }^{(101)}$, resulting in positive effects on cell adhesion, viability, growth, and differentiation. On the other hand, mussel adhesive proteins, with outstanding adhesive properties even in aqueous environment, have been used as scaffolds for bone regeneration ${ }^{(102)}$ and have inspired the generation of polydopamine in different formats, useful in re-endothelialization of artificial vessels ${ }^{(103)}$. They are commercially available as Cell-Tak (BD Bioscience, Corning), which is an extracted mixture of $f p-1$ and fp-2, 
useful to immobilize in vitro different cells and tissues on glass, plastic or even metals (Table 2).

Also, many non-natural peptides relevant to cell adhesion, proliferation and spreading have been obtained by genetic modification of natural sequences, by screening combinatorial peptide libraries and by combining bioinformatics and protein structural data to adjust and optimize adhesive properties for specific cell types. These strategies and the resulting peptides have been extensively revised and summarized elsewhere ${ }^{(104)}$.

Cell adhesion in bone tissue engineering. Many studies addressed to elucidate the molecular basis of osteogenesis from MSCs have demonstrated that substrate protein coating might be decisive in different phases of bone generation, mimicking the activities of corresponding soluble protein versions. FN to promote initial MSC adhesion and proliferation, bone morphogenetic protein 2 (BMP-2) as active agent in a second stage of differentiation and bone matrix production, osteopontin (OPN) and bone sialoprotein (BSP) to promote cell adhesion and differentiation into osteoblasts and osteoclasts, and tenascin (TN) to induce mineralization and new bone formation. Interestingly, FN effects differ depending on the type of coated material, probably due to conformational changes induced upon adsorption. In fact, the adhesion properties of OPN and BSP are enhanced when coated in their oligomerized forms (105).

\section{Developing functional drug-releasing biomaterials}

Hydrogel architecture. As mentioned above, the recreation of micro- and nano- topographies and cell-friendly surfaces for efficient attachment should be combined with biochemical signaling, desirably achieved by the release of soluble factors such as GFs, cytokines and other bioactive molecules (Figure 1). Among the broad range of available materials, the supramolecular organization of fibrous structures made of polysaccharides, proteins or short peptides can be easily modulated in terms of physicochemical features and can potentially act as reservoirs of soluble factors for their fine controlled release. In this context, hydrogels are injectable polymer-based biomaterials able to generate 3D networks with a huge potential in biomedicine. Interestingly, there is a broad catalogue of hydrogels, since they can be formed by different natural or synthetic polymers. Their generic architecture, swelling properties, pore size, interconnectivity, morphology and mechanical properties can be modulated through the fabrication of homopolymers, copolymers, by interpenetrating, double networking or by choosing covalent or physical interactions for the network construction ${ }^{(106)}$. Although hydrogels show by themselves interesting properties as scaffolds for tissue engineering, many efforts have been devoted to the development of artificial extracellular matrices based on hydrogels that offer not only mechanical but also biological cell-instructive cues, such as the targeted presentation of $\mathrm{GF}^{(107,108)}$.

Hydrogel-based GF release. GFs have critical roles in cell proliferation, differentiation and survival, being the main source of biomolecular cues in any tissue engineering approach. Specifically, BMPs, transforming GF (TGFs), vascular endothelial GF (VEGF), fibroblast GF (FGFs), nerve GF (NGF) and insulin-like GF (IGFs) are the most important soluble effectors 
involved in the tissue regeneration processes ${ }^{(109)}$ (Table 2). The administration of such GFs has already been tested through the injection of their soluble versions. However, first clinical trials have shown low efficiency due to uncontrolled delivery. In this regard, hydrogels have appeared as a promising scaffold for GF immobilization and sustained release ${ }^{(107)}$. On the one hand, through the immobilization of GFs in hydrogels, the stability as well as the specific spatio-temporal delivery of such key signaling molecules can be defined and improved. Moreover, further developments of such delivery platforms are expected to reduce the doses of GF to reach the desired effect. On the other hand, the embedment of such GF in hydrogel matrices allows the generation of biomaterials able to mimic both the biological and physicochemical functions of the extracellular milieu.

GFs (or any other drug of interest) can be immobilized in scaffolds and matrices by simple dispersion or physical entrapment, but also via biochemical or covalent links between the molecule of interest and the scaffold ${ }^{(110)}$. Since during the immobilization process, bioactivity of the protein or other drugs might be affected, a pre-treatment with poly-ethylenglycol (PEG) and an optimal buffer for drug encapsulation in micro- or -nanoparticles can notably improve the resulting bioavailability and bioactivity. Once immobilized, GFs are released from the scaffold by simple diffusion or via degradation of the polymeric matrix ${ }^{(109)}$. Promising prototypes of biomimetic hydrogels designed for GF delivery have been generated for skeletal regeneration, angiogenesis and vessel formation, and nerve regeneration, among others. Regarding bone tissue repair, different authors have proven the potential of different types of structures namely gelatine-poly(propylene)-based hydrogels ${ }^{(111)}$, hybrid hydrogels ${ }^{(107)}$, fibrinbased hydrogels ${ }^{(110)}$ and alginate-based hydrogels ${ }^{(112,113,114)}$, among others, combined with GFs. Interestingly, many of these studies have used GF-loaded microspheres to increase protein stability ${ }^{(111,107)}$, observing promising results in vitro.

Hydrogels for bone and cartilage regeneration. The combined delivery of TGF- $\beta 3$ and BMP-2 incorporated in alginate hydrogels is highly efficient and more effective for bone regeneration than free versions ${ }^{(112)}$. In agreement, the potential of GF release from hydrogels to regenerate bone tissue has been also demonstrated in rat, rabbit, sheep and dog ${ }^{(110)}$. As a complementary approach, the addition of integrin binding sites adjacent to GF-binding sites improves the final result ${ }^{(19)}$. Very recently, the generation of a novel and improved type of GF-releasing hydrogel has been described, able to stimulate ex vivo bone development and tissue repair ${ }^{(113,114)}$. Specifically, the authors have used a novel decellularized, demineralized bovine bone extracellular matrix combined with an alginate hydrogel as scaffold. Besides, this biomaterial was decorated with microparticles containing GFs and capable of releasing such GFs in a temporal and controlled manner. Individually, VEGF enhances cell migration, TGF- $\beta 3$ stimulates cell proliferation, and BMP-2 specifically enhances collagen deposition. However, dual combinations of these GFs show a synergic effect, being possible to simultaneously induce migration and collagen deposition when using VEGF and BMP-2, and observing a greatest influence on tissue deposition when combining TGF- $\beta 3$ and BMP-2 ${ }^{(113,114)}$. Furthermore, engineered hydrogels can be used to stimulate cartilage regeneration ${ }^{(115)}$. Considering that MSCs are a promising source for cartilage regeneration and that TGF- $\beta$ family has a key role in the chondrogenesis process of MSCs, Jung and collaborators have designed Cyclodextrin(CD)- 
and Cucurbituril(CB)-based hydrogels able to deliver TGF- $\beta$ through a spatiotemporal control in vivo, showing again promising results ${ }^{(115)}$.

Hydrogels for angiogenesis. Since angiogenesis is clearly dependent on the activity of GFs such as VEGF, FGFs and angiopoietin-1, hydrogels have a high potential as GF releasing systems also in this field. PEG-based hydrogels, combined with covalently-linked VEGF, have shown the ability not only to stimulate cell migration and proliferation, but also to maintain their viability ${ }^{(116,117)}$. Interestingly, it has been observed, as it has previously mentioned for skeletal tissue regeneration, an improved effect of RGD motifs when administered simultaneously to two GFs in both a chicken chorioallantoic membrane (CAM) assay and in an in vivo model ${ }^{(117)}$. In line with these studies, Thomas and co-workers have developed an advanced type of PEG hydrogels for localized and sustained delivery of angiogenic factors, using immobilized lentiviruses as GF expression system. Specifically, virus particles were incorporated in heparinchitosan nanoparticles, which were finally immobilized onto a PEG porous structure. Interestingly, an increase of endothelial cells and blood vessels around the hydrogel used was observed using both in vitro and in vivo approaches ${ }^{(118)}$.

Hydrogels for nerve tissue regeneration. Although the peripheral nervous system has a regenerative potential after nerve injury this not ensures complete tissue regeneration and in this context, hydrogels have also been used as controlled GF delivery platforms. For instance, a PLA-b-PEG-b-PLA microgel loaded with NGF and gelatin-based hydrogels loaded with VEGF ${ }^{(119)}$ have been extremely efficient. Microgels, which can be directly injected into the tissue, have shown the ability to release NGF through 22 days in vitro ${ }^{(120)}$. On the other hand, Gnavi and collaborators have evaluated VEGF release from gelatin-based hydrogels using Schwann cells and Dorsal root ganglia (DRG) explants (models for glia and motor neurons), concluding that this biomaterial induces neurite outgrowth from DRG explants ${ }^{(119)}$.

Amyloid engineering. Many protein and peptides have the natural capability to generate supramolecular fibrillar structures rich in beta-sheet conformation and stabilized by noncovalent interactions. This fact can be explained by the inherent physicochemical features of the protein and peptide backbone which exhibits a high propensity to establish hydrogen bonds, allowing the growth and stability of the protein/peptide amyloid fibers ${ }^{(121)}$. These amyloids, although firstly regarded as hazardous elements in several pathologies such as Alzheimer, Parkinson or Huntington disease are increasingly showing promise in the field of biomaterials as self-assembly protein fibrillar scaffolds. The capacity of generating a fibrillar matrix, resembling in composition and conformation the natural ECM, has focused the interest for this type of material in regenerative medicine, tissue engineering and other medical applications ${ }^{(122)}$. Additionally, the discovery of functional amyloids by Maji and co-workers, as reservoir of more than 30 releasable human hormones, opens the possibility of reaching a tight spatial and functional control of protein release from amyloid materials ${ }^{(123)}$. In this regard, amino acid stretches forming the amyloid building blocks can be chemically modified to finely regulate the disassembly of the fibrillar matrix. In particular, light-triggered release of the amyloid fibril building blocks can be an appealing and versatile approach. Measey et. al have provided evidence of how a simple substitution of lysines by a photocaged variant lys(Nvoc) allows the generation of amyloid fibrils with the capacity of disassembly upon irradiation with UV light. The lysNvoc light-mediated cleavage release the moiety attached to 
the side chain, restoring the regular amino acid properties and providing a significant change in the hydrophobicity that causes the disassembly of the amyloid fibril ${ }^{(124)}$.

Protein release from amyloid scaffolds. The plasticity shown by functional amyloids could be combined with other intrinsic features such as the slow release of the forming protein fibril. Elegant studies have tested the potential application of this platform for a sustained delivery of therapeutic proteins and peptides. This property would allow a significant improvement in treatments that require recurrent administration of the active molecule such as chronic or long-term diseases. In this context, amyloids formed by insulin or gonadotropin-releasing hormone $(\mathrm{GnRH})$ analogues have been successfully designed. Thus, supramolecular insulin assemblies (SIA) have been proposed as a long-term solution to current administration of the soluble version. Luo and co-workers combined the SIA in Layer by Layer (LbL) films in order to obtain an insulin reservoir with very tight control of the molecule release. Subcutaneous implants of SIA structured in LbL films were applied to diabetic rats allowing the control of the glucose levels in an accurate manner during 295 days ${ }^{(125)}$. Similarly, analogues of the GnRH can be used for the control of numerous sex steroid dependent pathophysiologies. These peptides are able to self-assemble in amyloid supramolecular structures with distinct stabilities and releasing properties depending on the analogue forming the amyloid fibril. Besides, subcutaneous implantation of $\mathrm{GnRH}$ analogs allowed the increase in the duration of the treatment compared to their soluble counterpart ${ }^{(126)}$.

Finally, bacterial IBs are functional amyloids that apart from the topographical potential for mechanical stimulation, cell adhesion and guidance discussed above, show high penetrability in mammalian cells and release the forming protein, in a functional form, inside cultured cells. These particles can be employed to add functionalities to 2D and 3D cell culture materials and exhibit a high versatility regarding the forming protein, its biological activity, and the physicochemical properties of the whole particle ${ }^{(127,128)}$. Such functionalized surfaces support the intracellular delivery of biologically active proteins to up to more than $80 \%$ of the colonizing cells, in a process slightly influenced by the chemical nature of the scaffold. The interesting combination of 3D soft scaffolds such as PLA and protein-based sustained release systems such as bacterial IBs (Bioscaffolds) (Table 2), offers promise in the fabrication of fully bio-inspired hybrid matrices for multifactorial control of cell proliferation in tissue engineering under complex architectonic setting-ups ${ }^{(129,130,131,132)}$. Although the uses in vivo of IBs and other amyloid materials could be restricted by their potential toxicity and immunogenicity, the growing amounts of promising data obtained in cell culture and the emerging concepts around functional and non-toxic functional amyloids ${ }^{(133)}$ prompt to envisage wide usability in ex vivo applications. Also, the absence of organic toxicity in oral administration of high IB doses ${ }^{(134)}$, the possibility to obtain these materials in LPS-free cell factories ${ }^{(135)}$ and the planned use of these particles to deliver homologous proteins such as GFs (then being formed by such homologous proteins) should ensure biocompatibility and minimize potential immune reactions in in situ tissue regeneration.

Drug release from functionalized amyloids. Apart from the direct release of the amyloid building blocks, these matrices can be also functionalized by soluble effectors, expanding the possibilities of action by providing multiple stimuli to the target cells (Figure 1). In this regard, simple co-incubation of the soluble effector during the supramolecular structure formation can 
be enough in order to entrap the soluble factor that would be progressively released during the degradation of the matrix. Following this principle, Chun et al incorporated retinoic acid to a K-casein amyloid hydrogel in order to gain control over neuronal differentiation ${ }^{(136)}$. Other approaches consist in modifying the backbone of the amyloid building block to incorporate a tag with a high affinity for a complementary motif, fused to the soluble factor. Specifically, the biotin-streptavidin pair has been successfully explored in order to functionalize amyloid fibrils without altering their fibrillar structure. Incorporating biotin to the peptide forming the amyloid fibril as well as to the IGF-1 and linking both through a multivalent streptavidin, Davis and co-workers obtained amyloids capable to improve cardiac myocyte survival and growth. Thus, culturing ex vivo these cardiac myocytes on IGF-1 functionalized amyloids improved their further response upon implantation of the biomaterial in rat models of myocardial infarction (137)

Peptide amphiphiles. Additionally to protein and peptide organization in amyloid structures, other molecules with peptidic nature confer extra levels of complexity to fibrillar architectures. In this regard, peptide amphiphiles (PA), generally composed by a peptidic hydrophilic head and an alkyl hydrophobic tail, allow the formation of micelles, fibers or even hollow tubes depending on the concrete nature of the PA used. Thus, we can find PA including cyclic peptides ${ }^{(138)}$, bolaamphiphiles ${ }^{(139)}$, surfactant-like peptides ${ }^{(140)}$ or aromatic dipeptides ${ }^{(141)}$. In general terms, the hydrophilic head is exposed to the solvent while the hydrophobic tails are disposed avoiding the contact with the solvent. As it happens with amyloid fibrils, PA selfassembly and stability are also due to non-covalent interactions. PA fibers allow a higher plasticity in the fiber supramolecular organization although their building blocks cannot act as the own soluble effectors and should be functionalized. PA self-assembled fibers have also proved their applicability as biomaterials. In this sense, PA fibers functionalized with IKVAV or RGD peptides are able to influence neuronal cell alignment and migration. Neuronal cell alignment onto these matrices rendered enhanced neurite growth in both in vitro and in vivo assays ${ }^{(142)}$. PA fibers also functionalized with the neuroactive peptide IKVAV were able to partially restore cognitive impairment upon PA-IKVAV injection into the hippocampus in Alzheimer's disease mice model. This result was linked to markedly neurogenesis observed in treated mice. Additionally, Yang and co-workers observed a decrease in the levels of soluble $a \beta-40$ a $\beta-42$ and amyloid- $\beta$ plaques probably derived from the IKVAV functionality ${ }^{(143)}$.

Table 2. Representative protein materials used for an integrated biological control of cell proliferation.

\begin{tabular}{|l|l|l|l|}
\hline Material & Presentation & Application & Reference \\
\hline $\begin{array}{l}\text { Mussel adhesive } \\
\text { proteins }\end{array}$ & Scaffold coated & $\begin{array}{l}\text { Enhances cell adhesion, } \\
\text { proliferation and } \\
\text { osteogenic formation in } \\
\text { vitro and in vivo }\end{array}$ & (102) \\
\hline Silk fibroin & Electrospun matrices & $\begin{array}{l}\text { Enhances adhesion of } \\
\text { different cell types in vitro }\end{array}$ & (101) \\
\hline Fibronectin & Coating surfaces & $\begin{array}{l}\text { Enhances adhesion and } \\
\text { retains regenerative } \\
\text { capacity of human } \\
\text { hematopoietic Stem Cells } \\
\text { ex vivo }\end{array}$ & (144) \\
\hline Laminin E8 & Coating surfaces & Support efficient & (145) \\
\hline
\end{tabular}




\begin{tabular}{|c|c|c|c|}
\hline fragment & & $\begin{array}{l}\text { adhesion and expansion of } \\
\text { dissociated human } \\
\text { pluripotent stem cells }\end{array}$ & \\
\hline Vitronectin & Coating surfaces & $\begin{array}{l}\text { Promote adhesion and } \\
\text { osteogenic diferenciation of } \\
\text { human mesenchymal stem } \\
\text { cells }\end{array}$ & (146) \\
\hline GFOGER & $\begin{array}{l}\text { Coating synthetic poly- } \\
\text { caprolactone }(\mathrm{PCL}) \\
\text { scaffolfs }\end{array}$ & $\begin{array}{l}\text { Increase and accelerate } \\
\text { bone formation in critically- } \\
\text { sized segmental defects in } \\
\text { rats }\end{array}$ & (147) \\
\hline Hialuronic acid (HA) & HA-binding scaffold & $\begin{array}{l}\text { Improved cartilage tissue } \\
\text { production in a rat knee } \\
\text { osteochondral defect } \\
\text { model }\end{array}$ & (148) \\
\hline $\begin{array}{l}\text { Elastin-like } \\
\text { polypeptides (ELP) } \\
\text { with fibronectin cs5 } \\
\text { and a proteolytic } \\
\text { domain }\end{array}$ & Absorbed to glass surfaces & $\begin{array}{l}\text { Enhance epithelial cell } \\
\text { attachment, proliferation, } \\
\text { and retention of the } \\
\text { differentiated } \\
\text { phenotype in ocular surface } \\
\text { tissue engineering }\end{array}$ & (149) \\
\hline Bone sialoprotein & $\begin{array}{l}\text { Surfaces coated with the } \\
\text { oligomerized form }\end{array}$ & $\begin{array}{l}\text { Promote osteoblast } \\
\text { adhesiveness }\end{array}$ & (150) \\
\hline Osteopontin & $\begin{array}{l}\text { Hydroxyapatite } \\
\text { nanoparticles } \\
\text { functionalized with } \\
\text { osteopontin (OPN) in a } \\
\text { matrix of poly-D,L-lactic- } \\
\text { acid (PDLLA) }\end{array}$ & $\begin{array}{l}\text { Increased the formation of } \\
\text { new bone in the porosities } \\
\text { of a canine implant }\end{array}$ & (151) \\
\hline TGF- $\beta$ & $\begin{array}{l}\text { Cyclodextrin(CD)- and } \\
\text { Cucurbituril(CB)-based } \\
\text { hydrogels }\end{array}$ & $\begin{array}{l}\text { Effective chondrogenic } \\
\text { differentiation }\end{array}$ & (115) \\
\hline VEGF & PEG-based hydrogels & $\begin{array}{l}\text { Stimulates cell migration } \\
\text { and proliferation and } \\
\text { maintain cell viability }\end{array}$ & $(116,117)$ \\
\hline VEGF & $\begin{array}{l}\text { Embedded in gelatine-like } \\
\text { gels }\end{array}$ & $\begin{array}{l}\text { Nerve grow stimulation in } \\
\text { in vitro models }\end{array}$ & (152) \\
\hline NGF & PLA-b-PEG-b-PLA microgel & $\begin{array}{l}\text { Material with potential to } \\
\text { maintain NGF activity in the } \\
\text { peripheral nervous system }\end{array}$ & (153) \\
\hline BFGF-2 & $\begin{array}{l}\text { In surface-coated } \\
\text { amyloidal micro-particles }\end{array}$ & $\begin{array}{l}\text { Stimulation of cell } \\
\text { proliferation in 2D and 3D } \\
\text { scaffolds }\end{array}$ & (132) \\
\hline TGF- $\beta 3$ and BMP-2 & $\begin{array}{l}\text { Embedded in alginate } \\
\text { hydogels }\end{array}$ & $\begin{array}{l}\text { Bone regeneration in in } \\
\text { vivo models }\end{array}$ & (112) \\
\hline TGF- $\beta 3$ and BMP-2 & $\begin{array}{l}\text { Embedded in alginate } \\
\text { hydogels }\end{array}$ & Improves tissue deposition & (113) \\
\hline VEGF and BMP-2 & $\begin{array}{l}\text { Embedded in alginate } \\
\text { hydogels }\end{array}$ & $\begin{array}{l}\text { Enhances migration and } \\
\text { collagen deposition }\end{array}$ & $(113,114)$ \\
\hline $\begin{array}{l}\text { Supramolecular } \\
\text { insulin assemblies } \\
\text { (SIA) }\end{array}$ & LbL films & $\begin{array}{l}\text { Long term control of } \\
\text { glucose levels }\end{array}$ & (125) \\
\hline GnRH analogues & Amyloid fibers & $\begin{array}{l}\text { Treatment of sex-steroid } \\
\text { dependent } \\
\text { pathophysiologies }\end{array}$ & (126) \\
\hline $\begin{array}{l}\text { Retinoic Acid - K- } \\
\text { Casein }\end{array}$ & $\begin{array}{l}\text { RA functionalizing amyloid } \\
\text { K casein hydrogel }\end{array}$ & Neuronal differentiation & (136) \\
\hline IGF-1 & $\begin{array}{l}\text { Functionalizing amyloid } \\
\text { fibrils }\end{array}$ & $\begin{array}{l}\text { Improve cardiac myocyte } \\
\text { survival and growth in }\end{array}$ & $(137)$ \\
\hline
\end{tabular}




\begin{tabular}{|l|l|l|l|}
\hline & & infarctation rat models & \\
\hline $\begin{array}{l}\text { Bacterial inclusion } \\
\text { bodies }\end{array}$ & $\begin{array}{l}\text { Functionalizing 2D and 3D } \\
\text { cell culture scaffolds }\end{array}$ & $\begin{array}{l}\text { Show promise as protein } \\
\text { drug delivery platform }\end{array}$ & (127) \\
\hline IKVAV or RGD & Functionalizing PA fibers & $\begin{array}{l}\text { In vitro and in vivo neurite } \\
\text { growth stimulation }\end{array}$ & (142) \\
\hline IKVAV & Functionalizing PA fibers & $\begin{array}{l}\text { Restores cognitive } \\
\text { impairment in Alzheimer's } \\
\text { disease }\end{array}$ & (143) \\
\hline IKVAV & $\begin{array}{l}\text { Immobilized on different } \\
\text { dextran-coated materials }\end{array}$ & $\begin{array}{l}\text { Promote substantial neuron } \\
\text { cell adhesion and neurite } \\
\text { outgrowth, and minimal } \\
\text { fibroblast and glial cell } \\
\text { adhesion }\end{array}$ & (154) \\
\hline
\end{tabular}

\section{Future perspective}

The comprehension of how cells respond to their environment, regarding the set of complex mechanical, biomechanical and biological stimuli provide by the ECM, is gained by the analyses of individual effectors or effector categories and their impact on cell biology. Then, 2D and 3D scaffolds are under development to offer appropriate surface roughness at both nano and micro scales to stimulate cell attachment, proliferation and differentiation and to modulate cell positioning and fate in regenerative medicine. In parallel, protein materials with appropriate biological and mechanical properties (such as adhesiveness) might serve for coating complicated scaffolds to provide more cell-friendly supports. In an attempt to integrate the range of stimuli, soluble protein factors, usually available upon external supply, are being incorporated into new-generation scaffolds, which act as topographies and simultaneously as drug reservoirs for sustained release along the tissue formation process. The expected gain of a temporal control over the activity of such hybrid materials and the resulting factor supply will necessarily conduce to designing smarter, bio-inspired scaffolds for a more accurate and integrative mimicry of cellular environment and a tighter control of tissue formation in artificial but biomimetic settings.

\section{Executive summary}

Engineering scaffold topography Engineering surface topology by either top-down or bottomup approaches offers a convenient way to modulate cell functions critical for tissue engineering such as attachment, proliferation, positioning, migration and differentiation.

Lithographic techniques are powerful instruments to topographically control cell behavior in modified scaffolds.

As a surface engineering method, particle deposition remains, instead, less dependent on the surface material chemistry and offers a high versatility in the control of patterning.

Diverse materials and biomaterials are suitable for the fabrication of biocompatible 2D and 3D scaffolds.

Surface-engineered 3D scaffolds offer extremely interesting settings for the structural mimicry of the ECM. 


\section{Tailoring bio-functional protein materials}

A set of natural or modified proteins and peptides allow coating of unfriendly materials for efficient cell colonization, enabling the applicability in tissue engineering of xenobiotic materials that are appealing from the fabrication point of view.

\section{Developing functional drug-releasing biomaterials}

Hydrogels and other polymeric materials adapted as 3D scaffolds for tissue engineering can be loaded with soluble protein factors with impact in tissue formation, for sustained release during cell colonization.

Hydrogels can be tuned and functionalized for very precise specific applications in tissue engineering such as nerve tissue regeneration and angiogenesis.

Full-length proteins resulting from biofabrication and natural or synthetic peptides are being engineered to form bio-inspired matrices for fast and efficient cell colonization.

Amyloidal materials are specifically suitable for the slow release of their bio-active building blocks, mimicking the performance of hormone secretory granules in the endocrine system and avoiding the external supply of soluble factors.

The combination of both topography and biological effectors in these protein materials offer a refreshing approach to the generation of bio-inspired, bio-active substrates (bioscaffolds) for tightly controlled, self-contained tissue engineering platforms. 


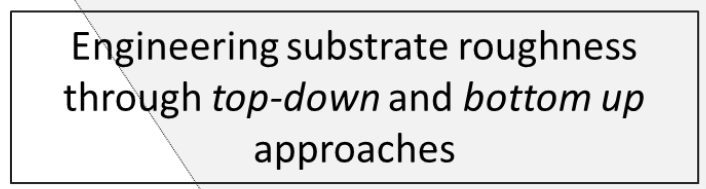
Versatile regulation of cell positioning, differentiation and activities by engineering deposited surface materials

Moving from 2D to 3D architectonic settings
Recombinant production of growth factors and other biological effectors for external supply

Engineering functional proteins to promote cell adhesion and colonization though surface coating

Design of fibers, hydrogels and related materials for local drug and GF delivery

Developing protein materials that supply in parallel proper topography features and biological function, trough releasable components and/or embedded drugs and GFs

Full mimicry of ECM architecture and function for the regulatable control of cell activities by an integrated combination of mechanical and biological stimuli

Figure 1. Tissue engineering requires both addressing substrate topography requirements at the cell sensing scale and providing appropriate biological stimuli for proper cell adhesion, positioning, migration, proliferation, differentiation and activity (top). This is intended to finely replicate ex vivo and in vivo features of the ECM in synthetic platforms, to finely regulate cell behavior in a targeted way (bottom). Plain engineering of surface topography through topdown and bottom up approaches have generated numerous insights about how cells respond to mechanical stimuli. On the other hand, soluble factors (mainly proteins) are progressively incorporated to 3D scaffolds for their local release, while proteins themselves are exploited for their adhesive properties and architectonic potential in form of coating layers, fibers, hydrogels and amyloids. Although still far from clinical implementation, bioinspired, hybrid and homogeneous protein materials are showing themselves as promising alternatives to separated topographical and biological effectors for an integrative manipulation of cells in tissue engineering. 


\section{Acknowledgments}

The authors acknowledge the financial support received for the design of protein-based materials from FIS (to E.V., PI12/00327), from La Marató de TV3 (to A.V., TV32013-132031 and to E.V. TV32013-133930), from INIA (to E.G.F., RTA2012-00028-C02-02), from MINECO (to A.V., BIO2013-41019-P) and from the Centro de Investigación Biomédica en Red (CIBER) de Bioingeniería, Biomateriales y Nanomedicina (NANOPROTHER project), financed by the Instituto de Salud Carlos III with assistance from the European Regional Development Fund. We are also indebted to the Protein Production Platform (CIBER-BBN-UAB) for helpful technical assistance (http://www.ciber-bbn.es/en/programas/89-plataforma-de-produccionde-proteinas-ppp). A.V. has been distinguished with an ICREA ACADEMIA Award.

\section{Selected articles: Of special interest:}

Clark, P., Connolly, P., Curtis, A. S., Dow, J. A., \& Wilkinson, C. D. (1990). Topographical control of cell behaviour: II. Multiple grooved substrata. Development, 108(4), 635-644.

One of the first uses of photolithography for preparation of grooved substrates with controlled geometry on the cell guidance.

Chen et al. Towards delivery of multiple growth factors in tissue engineering. Biomaterials. 2010. 31: 6279-6308.

In this article, the authors introduce the concept of dual and multiple delivery of growth factors for tissue engineering using several examples already published.

Dalby, M. J., Riehle, M. O., Johnstone, H., Affrossman, S., \& Curtis, A. S. G. (2002). In vitro reaction of endothelial cells to polymer demixed nanotopography. Biomaterials, 23(14), 29452954.

Study of endothelial cell response to nanotopography obtained by poymer demixing. It is demostrated, that morphological and cytoskeletal response depends on topographical feature size.

Reichl S 2009. Films based on human hair keratin as substrates for cell culture and tissue engineering. Biomaterials 30(36): 6854-6866.

This is a seminal article on the use of human hair keratin as a coating material for cell culture using novel methods for film generation and performing an exhaustive study on cell growth and epithelial tightness of different cell types.

Stukel et al. Polyethlyene glycol microgels to deliver bioactive nerve growth factor.J Biomed Mater Res A. 2014 Apr 26. doi: 10.1002/jbm.a.35209. [Epub ahead of print] This paper is an interesting in vivo example of the use of hydrogels as delivery platforms of growth factors with promising results in nerve tissue regeneration.

Yang Z et al. 2012. Mussel-Inspired Coating of Polydopamine Directs Endothelial and Smooth Muscle Cell Fate for Re-endothelialization of Vascular Devices. Advanced Healthcare Materials 1(5): 548-559. 
This is a nice example on the use of polydopamine (PDAM), a mussel adhesive protein inspired coating, as a vascular stent surface to promote endothelial function with a deep biocompatibility analysis.

Yang,H., Qu,T., Yang,H., Wei,L., Xie,Z., Wang,P., Bi,J., 2013. Self-assembling nanofibers improve cognitive impairment in a transgenic mice model of Alzheimer's disease. Neurosci. Lett., 556, 63-68.

Interesting in vivo example of PA nanofibers functionalization with the IKVAV motif.

\section{Of outstanding interest:}

Dalby, M. J., Gadegaard, N., Tare, R., Andar, A., Riehle, M. O., Herzyk, P., Wilkinson C. D. W.\& Oreffo, R. O. (2007). The control of human mesenchymal cell differentiation using nanoscale symmetry and disorder. Nature materials, 6(12), 997-1003.

Demonstration that the proper use of nanoscale modification of scaffolds stimulates human mesenchymal stem cells (MSCs) to produce bone mineral in vitro, in the absence of osteogenic supplements.

Maji,S.K., Perrin,M.H., Sawaya,M.R., Jessberger,S., Vadodaria,K., Rissman,R.A., Singru,P.S., Nilsson,K.P., Simon,R., Schubert,D., Eisenberg,D., Rivier,J., Sawchenko,P., Vale,W., Riek,R., 2009. Functional amyloids as natural storage of peptide hormones in pituitary secretory granules. Science, 325, 328-332.

In this work the authors unveil for the first time a number of peptide hormones being stored in releasable amyloids in the pituitary secretory granules. These functional amyloids evidence the need of rethinking the relationship between amyloids and amyloidal toxicity.

Smith et al. Evaluation of skeletal tissue repair, Part 1: Assessment of novel growth-factorreleasing hydrogels in an ex vivo chick femur defect model. Acta Biomater. 2014 Oct;10(10):4186-96. doi: 10.1016/j.actbio.2014.06.011. Epub 2014 Jun 14.

Smith et al. Evaluation of skeletal tissue repair, Part 2: Enhancement of skeletal tissue repair through dual-growth-factor-releasing hydrogels within an ex vivo chick femur defect model. Acta Biomater. 2014 Oct;10(10):4197-205. doi: 10.1016/j.actbio.2014.05.025. Epub 2014 Jun 4.

Both articles describe the use of a new and improved type of hydrogel for tissue engineering applications. This hydrogel has been combined, for the first time, with a decellularized and demineralized extracellular matrix and microparticles containing GFs with the aim to successfully mimic both the biological and physico-chemical functions of the extracellular environment.

Yim, E. K., Reano, R. M., Pang, S. W., Yee, A. F., Chen, C. S., \& Leong, K. W. (2005). Nanopattern-induced changes in morphology and motility of smooth muscle cells. Biomaterials, 26(26), 5405-5413.

Study of proliferation, motility and morphology of cells growing on PMMA and PDMS substrates with developed nanotopography. It is proposed that used nanoimprinting technology will provide a valuable platform for studies in cell-substrate interactions and for development of medical devices with nanoscale features.

Teixeira, A. I., Abrams, G. A., Bertics, P. J., Murphy, C. J., \& Nealey, P. F. (2003). Epithelial contact guidance on well-defined micro-and nanostructured substrates. Journal of cell science, 
116(10), 1881-1892.

This study documents that epithelial cell behavior is profoundly affected by biologic lengthscale topographic features.

Reference List

1. Dalby MJ: Nanostructured surfaces: cell engineering and cell biology. Nanomedicine.(Lond) 4(3), 247-248 (2009).

2. Griffith LG , Naughton G: Tissue engineering--current challenges and expanding opportunities. Science 295(5557), 1009-1014 (2002).

3. Lutolf MP, Hubbell JA: Synthetic biomaterials as instructive extracellular microenvironments for morphogenesis in tissue engineering. Nat.Biotechnol. 23(1), 47-55 (2005).

4. Vagaska B, Bacakova L, Filova E, Balik K: Osteogenic cells on bio-inspired materials for bone tissue engineering. Physiol Res. 59(3), 309-322 (2010).

5. Biggs MJ, Richards RG, Dalby MJ: Nanotopographical modification: a regulator of cellular function through focal adhesions. Nanomedicine. 6(5), 619-633 (2010).

6. Martinez E, Engel E, Planell JA, Samitier J: Effects of artificial micro- and nanostructured surfaces on cell behaviour. Ann.Anat. 191(1), 126-135 (2009).

7. Kantawong F, Burgess KE, Jayawardena $\mathrm{K}$ et al: Whole proteome analysis of osteoprogenitor differentiation induced by disordered nanotopography and mediated by ERK signalling. Biomaterials 30(27), 4723-4731 (2009).

8. Kantawong F, Burchmore R, Gadegaard N, Oreffo RO, Dalby MJ: Proteomic analysis of human osteoprogenitor response to disordered nanotopography. J.R.Soc.Interface 6(40), 1075-1086 (2009).

9. Heydarkhan-Hagvall $\mathrm{S}$, Choi $\mathrm{CH}$, Dunn J et al: Influence of systematically varied nanoscale topography on cell morphology and adhesion. Cell Commun.Adhes. 14(5), 181-194 (2007).

10. Uttayarat P, Toworfe GK, Dietrich F, Lelkes PI, Composto RJ: Topographic guidance of endothelial cells on silicone surfaces with micro- to nanogrooves: orientation of actin filaments and focal adhesions. J.Biomed.Mater.Res.A 75(3), 668-680 (2005).

11. McKee CT, Raghunathan VK, Nealey PF, Russell P, Murphy CJ: Topographic modulation of the orientation and shape of cell nuclei and their influence on the measured elastic modulus of epithelial cells. Biophys.J. 101(9), 2139-2146 (2011).

12. Lange SA, Benes V, Kern DP, Horber JK, Bernard A: Microcontact printing of DNA molecules. Anal.Chem. 76(6), 1641-1647 (2004).

13. Falconnet D, Csucs G, Grandin HM, Textor M: Surface engineering approaches to micropattern surfaces for cell-based assays. Biomaterials 27(16), 3044-3063 (2006).

14. Mrksich M, Dike LE, Tien J, Ingber DE, Whitesides GM: Using microcontact printing to pattern the attachment of mammalian cells to self-assembled monolayers of 
alkanethiolates on transparent films of gold and silver. Exp.Cell Res. 235(2), 305-313 (1997).

15. Zhang $S$, Yan L, Altman $M$ et al: Biological surface engineering: a simple system for cell pattern formation. Biomaterials 20(13), 1213-1220 (1999).

16. Raghavan S, Desai RA, Kwon Y, Mrksich M, Chen CS: Micropatterned dynamically adhesive substrates for cell migration. Langmuir 26(22), 17733-17738 (2010).

17. Yan X, Yao J, Lu G, Chen X, Zhang K, Yang B: Microcontact printing of colloidal crystals. J.Am.Chem.Soc. 126(34), 10510-10511 (2004).

18. Weibel DB, Lee $A$, Mayer $\mathrm{M}$ et al: Bacterial printing press that regenerates its ink: contact-printing bacteria using hydrogel stamps. Langmuir 21(14), 6436-6442 (2005).

19. Keefer EW, Botterman BR, Romero MI, Rossi AF, Gross GW: Carbon nanotube coating improves neuronal recordings. Nat.Nanotechnol. 3(7), 434-439 (2008).

20. Lipski AM, Pino CJ, Haselton FR, Chen IW, Shastri VP: The effect of silica nanoparticlemodified surfaces on cell morphology, cytoskeletal organization and function. Biomaterials 29, 3836-3846 (2008).

21. Ludden MJ, Mulder A, Tampe R, Reinhoudt DN, Huskens J: Molecular printboards as a general platform for protein immobilization: a supramolecular solution to nonspecific adsorption. Angew.Chem.Int.Ed Engl. 46(22), 4104-4107 (2007).

22. Samaroo HD, Lu J, Webster TJ: Enhanced endothelial cell density on NiTi surfaces with sub-micron to nanometer roughness. Int.J.Nanomedicine. 3(1), 75-82 (2008).

23. Park J, Bauer S, von der MK, Schmuki P: Nanosize and vitality: TiO2 nanotube diameter directs cell fate. Nano.Lett. 7(6), 1686-1691 (2007).

24. Namgung S, Baik KY, Park J, Hong S: Controlling the growth and differentiation of human mesenchymal stem cells by the arrangement of individual carbon nanotubes. ACS Nano. 5(9), 7383-7390 (2011).

25. Charest JL, Eliason MT, Garcia AJ, King WP: Combined microscale mechanical topography and chemical patterns on polymer cell culture substrates. Biomaterials 27(11), 2487-2494 (2006).

26. Feinberg AW, Wilkerson WR, Seegert CA, Gibson AL, Hoipkemeier-Wilson L, Brennan $A B$ : Systematic variation of microtopography, surface chemistry and elastic modulus and the state dependent effect on endothelial cell alignment. J.Biomed.Mater.Res.A 86(2), 522-534 (2008).

27. Recknor JB, Sakaguchi DS, Mallapragada SK: Directed growth and selective differentiation of neural progenitor cells on micropatterned polymer substrates. Biomaterials 27(22), 4098-4108 (2006).

28. García-Fruitós E, Rodríguez-Carmona E, Díez-Gil C et al: Surface Cell Growth Engineering Assisted by a Novel Bacterial Nanomaterial. Advanced Materials 21, 4249-4253 (2009).

29. Diez-Gil C, Krabbenborg S, Garcia-Fruitos E et al: The nanoscale properties of bacterial inclusion bodies and their effect on mammalian cell proliferation. Biomaterials 31(22), 5805-5812 (2010).

30. Seras-Franzoso J, Diez-Gil C, Vazquez E et al: Bioadhesiveness and efficient mechanotransduction stimuli synergistically provided by bacterial inclusion 
bodies as scaffolds for tissue engineering. Nanomedicine.(Lond) 7(1), 79-93 (2012).

31. Tatkiewicz WI, Seras-Franzoso J, Garcia-Fruitos E et al: Two-dimensional microscale engineering of protein-based nanoparticles for cell guidance. ACS Nano. 7(6), 4774-4784 (2013).

32. Khang D, Carpenter J, Chun YW, Pareta R, Webster TJ: Nanotechnology for regenerative medicine. Biomed.Microdevices. 12(4), 575-587 (2010).

33. Navarro M, Michiardi A, Castano O, Planell JA: Biomaterials in orthopaedics. J.R.Soc.Interface 5(27), 1137-1158 (2008).

34. Bonzani IC, George JH, Stevens MM: Novel materials for bone and cartilage regeneration. Curr.Opin.Chem.Biol. 10(6), 568-575 (2006).

35. Hollister SJ: Porous scaffold design for tissue engineering. Nat.Mater 4(7), 518-524 (2005).

36. Dalby MJ, Gadegaard N, Tare R et al: The control of human mesenchymal cell differentiation using nanoscale symmetry and disorder. Nat.Mater. 6(12), 9971003 (2007).

37. Huang $D$, Zuo Y, Li J et al: Bioactive composite gradient coatings of nanohydroxyapatite/polyamide66 fabricated on polyamide66 substrates. J.R.Soc.Interface 9(72), 1450-1457 (2012).

38. Su $B$, Peng $X$, Jiang $D$ et al: In vitro and in vivo evaluations of nanohydroxyapatite/polyamide 66/glass fibre (n-HA/PA66/GF) as a novel bioactive bone screw. PLoS.One. 8(7), e68342- (2013).

39. Huang D, Zuo Y, Zou Q et al: Antibacterial chitosan coating on nanohydroxyapatite/polyamide66 porous bone scaffold for drug delivery. J.Biomater.Sci.Polym.Ed 22(7), 931-944 (2011).

40. Wojciak-Stothard B, Madeja Z, Korohoda W, Curtis A, Wilkinson C: Activation of macrophage-like cells by multiple grooved substrata. Topographical control of cell behaviour. Cell Biol.Int. 19(6), 485-490 (1995).

41. Wood A: Contact guidance on microfabricated substrata: the response of teleost fin mesenchyme cells to repeating topographical patterns. J.Cell Sci. 90 ( Pt 4), 667-681 (1988).

42. Dalby MJ, Riehle MO, Yarwood SJ, Wilkinson CD, Curtis AS: Nucleus alignment and cell signaling in fibroblasts: response to a micro-grooved topography. Exp.Cell Res. 284(2), 274-282 (2003).

43. Wojciak-Stothard B, Curtis A, Monaghan W, MacDonald K, Wilkinson C: Guidance and activation of murine macrophages by nanometric scale topography. Exp.Cell Res. 223(2), 426-435 (1996). 
44. Rajnicek AM, Foubister LE, McCaig CD: Prioritising guidance cues: directional migration induced by substratum contours and electrical gradients is controlled by a rho/cdc42 switch. Dev.Biol. 312(1), 448-460 (2007).

45. Teixeira Al, Abrams GA, Bertics PJ, Murphy CJ, Nealey PF: Epithelial contact guidance on well-defined micro- and nanostructured substrates. J.Cell Sci. 116(Pt 10), 1881-1892 (2003).

46. Meyle J, Gultig K, Nisch W: Variation in contact guidance by human cells on a microstructured surface. J.Biomed.Mater.Res. 29(1), 81-88 (1995).

47. Clark P, Connolly P, Curtis AS, Dow JA, Wilkinson CD: Topographical control of cell behaviour: II. Multiple grooved substrata. Development 108(4), 635-644 (1990).

48. Dalby MJ, Riehle MO, Sutherland DS, Agheli H, Curtis AS: Changes in fibroblast morphology in response to nano-columns produced by colloidal lithography. Biomaterials 25(23), 5415-5422 (2004).

49. Dalby, M J, Gadegaard N, Riehlea MO, Wilkinson CDW , Curtis ASG. Investigating filopodia sensing using arrays of defined nano-pits down to $35 \mathrm{~nm}$ diameter in size. The International Journal of Biochemistry \& Cell Biology 36 (10), 20052015 (2004)

50. Curtis ASG, Casey B, Gallagher JO, Pasqui D, Wood MA, Wilkinson CDW. Substratum nanotopography and the adhesion of biological cells. Are symmetry or regularity of nanotopography important? Biophysical Chemistry. 94 (3), 275283 (2001)

51. Curtis ASG, Gadegaard N,Dalby MJ, Riehle M, Wilkinson CDW, Aitchison G. Cells react to nanoscale order and symmetry in their surroundings. NanoBioscience 3 (1), $61-65(2004)$

52. Curtis AS, Gadegaard N, Dalby MJ, Riehle MO, Wilkinson CD, Aitchison G: Cells react to nanoscale order and symmetry in their surroundings. IEEE Trans.Nanobioscience. 3(1), 61-65 (2004).

53. Dalby MJ, Gadegaard N, Riehle MO, Wilkinson CD, Curtis AS: Investigating filopodia sensing using arrays of defined nano-pits down to $35 \mathrm{~nm}$ diameter in size. Int.J.Biochem.Cell Biol. 36(10), 2005-2015 (2004).

54. Curtis AS, Casey B, Gallagher JO, Pasqui D, Wood MA, Wilkinson CD: Substratum nanotopography and the adhesion of biological cells. Are symmetry or regularity of nanotopography important? Biophys.Chem 94(3), 275-283 (2001).

55. Recknor JB, Recknor JC, Sakaguchi DS, Mallapragada SK: Oriented astroglial cell growth on micropatterned polystyrene substrates. Biomaterials 25(14), 2753-2767 (2004).

56. Loesberg WA, te RJ, van Delft FC et al: The threshold at which substrate nanogroove dimensions may influence fibroblast alignment and adhesion. Biomaterials 28(27), 3944-3951 (2007). 
57. Matsuzaka K, Walboomers XF, Yoshinari M, Inoue T, Jansen JA: The attachment and growth behavior of osteoblast-like cells on microtextured surfaces. Biomaterials 24(16), 2711-2719 (2003).

58. - Bruinink, A, - Wintermantel, E: - Grooves affect primary bone marrow but not osteoblastic MC3T3-E1 cell cultures.

59. Wang X, Ohlin CA, Lu Q, Hu J: Cell directional migration and oriented division on threedimensional laser-induced periodic surface structures on polystyrene. Biomaterials 29(13), 2049-2059 (2008).

60. Rebollar E, Frischauf I, Olbrich $\mathrm{M}$ et al: Proliferation of aligned mammalian cells on laser-nanostructured polystyrene. Biomaterials 29(12), 1796-1806 (2008).

61. Dalton BA, Walboomers XF, Dziegielewski M et al: Modulation of epithelial tissue and cell migration by microgrooves. J.Biomed.Mater.Res. 56(2), 195-207 (2001).

62. Nomura S, Kojima H, Ohyabu Y, Kuwabara K, Miyauchi A, Uemura T: Nanopillar sheets as a new type of cell culture dish: detailed study of HeLa cells cultured on nanopillar sheets. J.Artif.Organs 9(2), 90-96 (2006).

63. Dalby MJ, Riehle MO, Johnstone $\mathrm{H}$, Affrossman S, Curtis AS: In vitro reaction of endothelial cells to polymer demixed nanotopography. Biomaterials 23(14), 2945-2954 (2002).

64. Charest JL, Bryant LE, Garcia AJ, King WP: Hot embossing for micropatterned cell substrates. Biomaterials 25(19), 4767-4775 (2004).

65. Miller C, Shanks H, Witt A, Rutkowski G, Mallapragada S: Oriented Schwann cell growth on micropatterned biodegradable polymer substrates. Biomaterials 22(11), 1263-1269 (2001).

66. Thapa A, Webster TJ, Haberstroh KM: Polymers with nano-dimensional surface features enhance bladder smooth muscle cell adhesion. J.Biomed.Mater.Res.A 67(4), 1374-1383 (2003).

67. Meyle J, Wolburg H, von Recum AF: Surface micromorphology and cellular interactions. J.Biomater.Appl. 7(4), 362-374 (1993).

68. Matsuzaka K, Walboomers XF, de Ruijter JE, Jansen JA: The effect of poly-L-lactic acid with parallel surface micro groove on osteoblast-like cells in vitro. Biomaterials 20(14), 1293-1301 (1999).

69. Gerecht S, Bettinger CJ, Zhang Z, Borenstein JT, Vunjak-Novakovic G, Langer R: The effect of actin disrupting agents on contact guidance of human embryonic stem cells. Biomaterials 28(28), 4068-4077 (2007).

70. Green AM, Jansen JA, van der Waerden JP, von Recum AF: Fibroblast response to microtextured silicone surfaces: texture orientation into or out of the surface. J.Biomed.Mater.Res. 28(5), 647-653 (1994). 
71. Bettinger CJ, Zhang Z, Gerecht S, Borenstein JT, Langer R: Enhancement of In Vitro Capillary Tube Formation by Substrate Nanotopography. Adv.Mater. 20(1), 99103 (2008).

72. Yim EK, Pang SW, Leong KW: Synthetic nanostructures inducing differentiation of human mesenchymal stem cells into neuronal lineage. Exp.Cell Res. 313(9), 1820-1829 (2007).

73. Dalby MJ, McCloy D, Robertson $\mathrm{M}$ et al: Osteoprogenitor response to semi-ordered and random nanotopographies. Biomaterials 27(15), 2980-2987 (2006).

74. Dalby MJ, Riehle MO, Sutherland DS, Agheli H, Curtis AS: Fibroblast response to a controlled nanoenvironment produced by colloidal lithography.

J.Biomed.Mater.Res.A 69(2), 314-322 (2004).

75. Yim EK, Reano RM, Pang SW, Yee AF, Chen CS, Leong KW: Nanopattern-induced changes in morphology and motility of smooth muscle cells. Biomaterials 26(26), 5405-5413 (2005).

76. Miller DC, Thapa A, Haberstroh KM, Webster TJ: Endothelial and vascular smooth muscle cell function on poly(lactic-co-glycolic acid) with nano-structured surface features. Biomaterials 25(1), 53-61 (2004).

77. Kim DH, Kim P, Suh K, Kyu CS, Ho LS, Kim B: Modulation of adhesion and growth of cardiac myocytes by surface nanotopography. Conf.Proc.IEEE Eng Med.Biol.Soc. 4, 4091-4094 (2005).

78. Kim P, Kim DH, Kim B et al: Fabrication of nanostructures of polyethylene glycol for applications to protein adsorption and cell adhesion. Nanotechnology. 16(10), 2420-2426 (2005).

79. Hart A, Gadegaard N, Wilkinson CD, Oreffo RO, Dalby MJ: Osteoprogenitor response to low-adhesion nanotopographies originally fabricated by electron beam lithography. J.Mater.Sci.Mater.Med. 18(6), 1211-1218 (2007).

80. Biggs MJ, Richards RG, Gadegaard N, Wilkinson CD, Dalby MJ: The effects of nanoscale pits on primary human osteoblast adhesion formation and cellular spreading. J.Mater.Sci.Mater.Med. 18(2), 399-404 (2007).

81. Bettinger CJ, Orrick B, Misra A, Langer R, Borenstein JT: Microfabrication of poly (glycerol-sebacate) for contact guidance applications. Biomaterials 27(12), 2558-2565 (2006).

82. Choi CH, Hagvall SH, Wu BM, Dunn JC, Beygui RE, CJ Kim CJ: Cell interaction with threedimensional sharp-tip nanotopography. Biomaterials 28(9), 1672-1679 (2007).

83. Foley JD, Grunwald EW, Nealey PF, Murphy CJ: Cooperative modulation of neuritogenesis by PC12 cells by topography and nerve growth factor. Biomaterials 26(17), 3639-3644 (2005).

84. Karuri NW, Liliensiek S, Teixeira Al et al: Biological length scale topography enhances cell-substratum adhesion of human corneal epithelial cells. J.Cell Sci. 117(Pt 15), 3153-3164 (2004). 
85. Chou L, Firth JD, Uitto VJ, Brunette DM: Substratum surface topography alters cell shape and regulates fibronectin mRNA level, mRNA stability, secretion and assembly in human fibroblasts. J.Cell Sci. 108 ( Pt 4), 1563-1573 (1995).

86. Lu J, Rao MP, MacDonald NC, Khang D, Webster TJ: Improved endothelial cell adhesion and proliferation on patterned titanium surfaces with rationally designed, micrometer to nanometer features. Acta Biomater. 4(1), 192-201 (2008).

87. Andersson AS, Backhed F, von EA, Richter-Dahlfors A, Sutherland D, Kasemo B: Nanoscale features influence epithelial cell morphology and cytokine production. Biomaterials 24(20), 3427-3436 (2003).

88. Popat KC, Chatvanichkul KI, Barnes GL, Latempa TJ, Jr., Grimes CA, Desai TA: Osteogenic differentiation of marrow stromal cells cultured on nanoporous alumina surfaces. J.Biomed.Mater.Res.A 80(4), 955-964 (2007).

89. Kunzler TP, Huwiler C, Drobek T, Voros J, Spencer ND: Systematic study of osteoblast response to nanotopography by means of nanoparticle-density gradients. Biomaterials 28(33), 5000-5006 (2007).

90. Shekaran A , Garcia AJ: Extracellular matrix-mimetic adhesive biomaterials for bone repair. J.Biomed.Mater.Res.A 96(1), 261-272 (2011).

91. Vroman L, Adams AL: Identification of rapid changes at plasma-solid interfaces. J.Biomed.Mater.Res. 3(1), 43-67 (1969).

92. Wilson K, Stuart SJ, Garcia A, Latour RA, Jr.: A molecular modeling study of the effect of surface chemistry on the adsorption of a fibronectin fragment spanning the 710th type III repeats. J.Biomed.Mater.Res.A 69(4), 686-698 (2004).

93. Kaufmann D, Fiedler A, Junger A, Auernheimer J, Kessler H, Weberskirch R: Chemical conjugation of linear and cyclic RGD moieties to a recombinant elastin-mimetic polypeptide--a versatile approach towards bioactive protein hydrogels. Macromol.Biosci. 8(6), 577-588 (2008).

94. Webster TJ, Ahn ES: Nanostructured biomaterials for tissue engineering bone. Adv.Biochem.Eng Biotechnol. 103, 275-308 (2007).

95. von der MK, Park J, Bauer S, Schmuki P: Nanoscale engineering of biomimetic surfaces: cues from the extracellular matrix. Cell Tissue Res. 339(1), 131-153 (2010).

96. Reichl S: Films based on human hair keratin as substrates for cell culture and tissue engineering. Biomaterials 30(36), 6854-6866 (2009).

97. Almine JF, Bax DV, Mithieux SM et al: Elastin-based materials. Chem.Soc.Rev. 39(9), 3371-3379 (2010).

98. Kundu B, Rajkhowa R, Kundu SC, Wang X: Silk fibroin biomaterials for tissue regenerations. Adv.Drug Deliv.Rev. 65(4), 457-470 (2013).

99. Min BM, Lee G, Kim SH, Nam YS, Lee TS, Park WH: Electrospinning of silk fibroin nanofibers and its effect on the adhesion and spreading of normal human keratinocytes and fibroblasts in vitro. Biomaterials 25(7-8), 1289-1297 (2004).

100. Jin HJ, Chen J, Karageorgiou V, Altman GH, Kaplan DL: Human bone marrow stromal cell responses on electrospun silk fibroin mats. Biomaterials 25(6), 1039-1047 (2004).

101. Zhang $X$, Baughman CB, Kaplan DL: In vitro evaluation of electrospun silk fibroin scaffolds for vascular cell growth. Biomaterials 29(14), 2217-2227 (2008). 
102. Hong JM, Kim BJ, Shim JH et al: Enhancement of bone regeneration through facile surface functionalization of solid freeform fabrication-based threedimensional scaffolds using mussel adhesive proteins. Acta Biomater. 8(7), 2578-2586 (2012).

103. Yang Z, Tu Q, Zhu Y et al: Mussel-inspired coating of polydopamine directs endothelial and smooth muscle cell fate for re-endothelialization of vascular devices. Adv. Healthc.Mater. 1(5), 548-559 (2012).

104. Sreejalekshmi KG , Nair PD: Biomimeticity in tissue engineering scaffolds through synthetic peptide modifications-altering chemistry for enhanced biological response. J.Biomed.Mater.Res.A 96(2), 477-491 (2011).

105. Chatakun P, Nunez-Toldra R, az Lopez EJ et al: The effect of five proteins on stem cells used for osteoblast differentiation and proliferation: a current review of the literature. Cell Mol.Life Sci. 71(1), 113-142 (2014).

106. Kopecek J , Yang J: Smart self-assembled hybrid hydrogel biomaterials. Angew.Chem.Int.Ed Engl. 51(30), 7396-7417 (2012).

107. Chen FM, Zhang M, Wu ZF: Toward delivery of multiple growth factors in tissue engineering. Biomaterials 31(24), 6279-6308 (2010).

108. Jiang Y, Chen J, Deng C, Suuronen EJ, Zhong Z: Click hydrogels, microgels and nanogels: emerging platforms for drug delivery and tissue engineering. Biomaterials 35(18), 4969-4985 (2014).

109. Ladewig K: Drug delivery in soft tissue engineering. Expert Opin.Drug Deliv. 8(9), 11751188 (2011).

110. Lienemann PS, Lutolf MP, Ehrbar M: Biomimetic hydrogels for controlled biomolecule delivery to augment bone regeneration. Adv.Drug Deliv. Rev. 64(12), 10781089 (2012).

111. Kempen DH, Lu L, Heijink A et al: Effect of local sequential VEGF and BMP-2 delivery on ectopic and orthotopic bone regeneration. Biomaterials 30(14), 2816-2825 (2009).

112. Simmons CA, Alsberg E, Hsiong S, Kim WJ, Mooney DJ: Dual growth factor delivery and controlled scaffold degradation enhance in vivo bone formation by transplanted bone marrow stromal cells. Bone 35(2), 562-569 (2004).

113. Smith EL, Kanczler JM, Gothard D et al: Evaluation of skeletal tissue repair, Part 1: Assessment of novel growth-factor-releasing hydrogels in an ex vivo chick femur defect model. Acta Biomater. (2014).

114. Smith EL, Kanczler JM, Gothard D et al: Evaluation of skeletal tissue repair, Part 2: Enhancement of skeletal tissue repair through dual-growth-factor-releasing hydrogels within an ex vivo chick femur defect model. Acta Biomater. (2014).

115. Jung H, Park JS, Yeom J et al: 3D tissue engineered supramolecular hydrogels for controlled chondrogenesis of human mesenchymal stem cells. Biomacromolecules 15(3), 707-714 (2014).

116. Porter AM, Klinge CM, Gobin AS: Biomimetic hydrogels with VEGF induce angiogenic processes in both hUVEC and hMEC. Biomacromolecules 12(1), 242-246 (2011). 
117. Zieris A, Chwalek K, Prokoph S et al: Dual independent delivery of pro-angiogenic growth factors from starPEG-heparin hydrogels. J.Control Release 156(1), 2836 (2011).

118. Thomas AM, Gomez AJ, Palma JL, Yap WT, Shea LD: Heparin-chitosan nanoparticle functionalization of porous poly(ethylene glycol) hydrogels for localized lentivirus delivery of angiogenic factors. Biomaterials 35(30), 8687-8693 (2014).

119. Gnavi S, di BL, Tonda-Turo C et al: Gelatin-based hydrogel for vascular endothelial growth factor release in peripheral nerve tissue engineering. J.Tissue Eng Regen.Med. (2014).

120. Stukel J, Thompson S, Simon L, Willits R: Polyethlyene glycol microgels to deliver bioactive nerve growth factor. J.Biomed.Mater.Res.A (2014).

121. Knowles TP, Buehler MJ: Nanomechanics of functional and pathological amyloid materials. Nat.Nanotechnol. 6(8), 469-479 (2011).

122. Mitraki A: Protein aggregation from inclusion bodies to amyloid and biomaterials. Adv.Protein Chem.Struct.Biol. 79, 89-125 (2010).

123. Maji SK, Perrin MH, Sawaya MR et al: Functional amyloids as natural storage of peptide hormones in pituitary secretory granules. Science 325(5938), 328-332 (2009).

124. Measey TJ , Gai F: Light-triggered disassembly of amyloid fibrils. Langmuir 28(34), 12588-12592 (2012).

125. Luo J, Cao S, Chen X et al: Super long-term glycemic control in diabetic rats by glucosesensitive LbL films constructed of supramolecular insulin assembly. Biomaterials 33(33), 8733-8742 (2012).

126. Maji SK, Schubert D, Rivier C, Lee S, Rivier JE, Riek R: Amyloid as a depot for the formulation of long-acting drugs. PLoS.Biol. 6(2), e17- (2008).

127. Seras-Franzoso J, Steurer C, Roldan M et al: Functionalization of 3D scaffolds with protein-releasing biomaterials for intracellular delivery. J.Control Release 171(1), 63-72 (2013).

128. Diez-Gil C, Krabbenborg S, Garcia-Fruitos E et al: The nanoscale properties of bacterial inclusion bodies and their effect on mammalian cell proliferation. Biomaterials 31(22), 5805-5812 (2010).

129. Cano-Garrido O, Rodriguez-Carmona E, Díez-Gil C et al: Supramolecular organization of protein-releasing functional amyloids solved in bacterial inclusion bodies. Acta Biomater. 9(4), 6134-6142 (2013).

130. Seras-Franzoso J, Peebo K, Corchero JL, Tsimbouri PM, Unzueta U, Rinas U, Dalby M, Vazquez E, García-Fruitós E, and Villaverde A. A nanostructured bacterial bioscaffold for the sustained bottom-up delivery of protein drugs. Nanomedicine (Lond) (2013) 
131. Seras-Franzoso J, Tsimbouri PM, Burgess KV et al: Topographically targeted osteogenesis of mesenchymal stem cells stimulated by inclusion bodies attached to polycaprolactone surfaces. Nanomedicine (Lond) 9, 207-220 (2014).

132. Seras-Franzoso J, Peebo K, Garcia-Fruitos E, Vazquez E, Rinas U, Villaverde A: Improving protein delivery of fibroblast growth factor-2 from bacterial inclusion bodies used as cell culture substrates. Acta Biomater. 10 , 1354-1359 (2013).

133. Mankar S, Anoop A, Sen S, Maji SK: Nanomaterials: amyloids reflect their brighter side. Nano Rev. 2 (2011).

134. Vazquez E, Corchero JL, Burgueno JF et al: Functional Inclusion Bodies Produced in Bacteria as Naturally Occurring Nanopills for Advanced Cell Therapies. Adv.Mater. 24(13), 1742-1747 (2012).

135. Rueda F, Cano-Garrido O, Mamat U et al: Production of functional inclusion bodies in endotoxin-free Escherichia coli. Appl.Microbiol.Biotechnol. 98(22), 9229-9238 (2014).

136. Chun J, Bhak G, Lee SG et al: kappa-Casein-based hierarchical suprastructures and their use for selective temporal and spatial control over neuronal differentiation. Biomacromolecules. 13(9), 2731-2738 (2012).

137. Davis ME, Hsieh PC, Takahashi T et al: Local myocardial insulin-like growth factor 1 (IGF-1) delivery with biotinylated peptide nanofibers improves cell therapy for myocardial infarction. Proc.Natl.Acad.Sci.U.S.A 103(21), 8155-8160 (2006).

138. Ghadiri MR, Granja JR, Milligan RA, McRee DE, Khazanovich N: Self-assembling organic nanotubes based on a cyclic peptide architecture. Nature 366(6453), 324-327 (1993).

139. Claussen RC, Rabatic BM, Stupp SI: Aqueous self-assembly of unsymmetric Peptide bolaamphiphiles into nanofibers with hydrophilic cores and surfaces.

J.Am.Chem.Soc. 125(42), 12680-12681 (2003).

140. Vauthey S, Santoso S, Gong H, Watson N, Zhang S: Molecular self-assembly of surfactant-like peptides to form nanotubes and nanovesicles.

Proc.NatI.Acad.Sci.U.S.A 99(8), 5355-5360 (2002).

141. Reches M , Gazit E: Casting metal nanowires within discrete self-assembled peptide nanotubes. Science 300(5619), 625-627 (2003).

142. Berns EJ, Sur S, Pan L et al: Aligned neurite outgrowth and directed cell migration in self-assembled monodomain gels. Biomaterials 35(1), 185-195 (2014).

143. Yang $H, Q u T$, Yang $H$ et al: Self-assembling nanofibers improve cognitive impairment in a transgenic mice model of Alzheimer's disease. Neurosci.Lett. 556, 63-68 (2013). 
144. Dao MA, Hashino K, Kato I, Nolta JA: Adhesion to fibronectin maintains regenerative capacity during ex vivo culture and transduction of human hematopoietic stem and progenitor cells. Blood 92(12), 4612-4621 (1998).

145. Miyazaki T, Futaki S, Suemori H et al: Laminin E8 fragments support efficient adhesion and expansion of dissociated human pluripotent stem cells. Nat.Commun. 3, 1236- (2012).

146. Salasznyk RM, Williams WA, Boskey A, Batorsky A, Plopper GE: Adhesion to Vitronectin and Collagen I Promotes Osteogenic Differentiation of Human Mesenchymal Stem Cells. J.Biomed.Biotechnol. 2004(1), 24-34 (2004).

147. Wojtowicz AM, Shekaran A, Oest ME et al: Coating of biomaterial scaffolds with the collagen-mimetic peptide GFOGER for bone defect repair. Biomaterials 31(9), 2574-2582 (2010).

148. Unterman SA, Gibson M, Lee JH et al: Hyaluronic acid-binding scaffold for articular cartilage repair. Tissue Eng Part A 18(23-24), 2497-2506 (2012).

149. Martinez-Osorio H, Juarez-Campo M, Diebold $\mathrm{Y}$ et al: Genetically engineered elastinlike polymer as a substratum to culture cells from the ocular surface. Curr.Eye Res. 34(1), 48-56 (2009).

150. Forsprecher J, Wang Z, Goldberg HA, Kaartinen MT: Transglutaminase-mediated oligomerization promotes osteoblast adhesive properties of osteopontin and bone sialoprotein. Cell Adh.Migr. 5(1), 65-72 (2011).

151. Jensen T, Baas J, Dolathshahi-Pirouz A et al: Osteopontin functionalization of hydroxyapatite nanoparticles in a PDLLA matrix promotes bone formation. J.Biomed.Mater Res.A 99(1), 94-101 (2011).

152. Gnavi S, di BL, Tonda-Turo C et al: Gelatin-based hydrogel for vascular endothelial growth factor release in peripheral nerve tissue engineering. J.Tissue Eng Regen.Med. (2014).

153. Stukel J, Thompson S, Simon L, Willits R: Polyethlyene glycol microgels to deliver bioactive nerve growth factor. J.Biomed.Mater.Res.A (2014).

154. Massia SP, Holecko MM, Ehteshami GR: In vitro assessment of bioactive coatings for neural implant applications. J.Biomed.Mater Res.A 68(1), 177-186 (2004). 